Prepared in cooperation with the Lahontan Regional Water Quality Control Board and the State Water Resources Control Board

\title{
Geologic Map and Borehole Stratigraphy of Hinkley Valley and Vicinity, San Bernardino County, California
}

By David M. Miller, Victoria E. Langenheim, and Elizabeth K. Haddon

Pamphlet to accompany

Scientific Investigations Map 3458

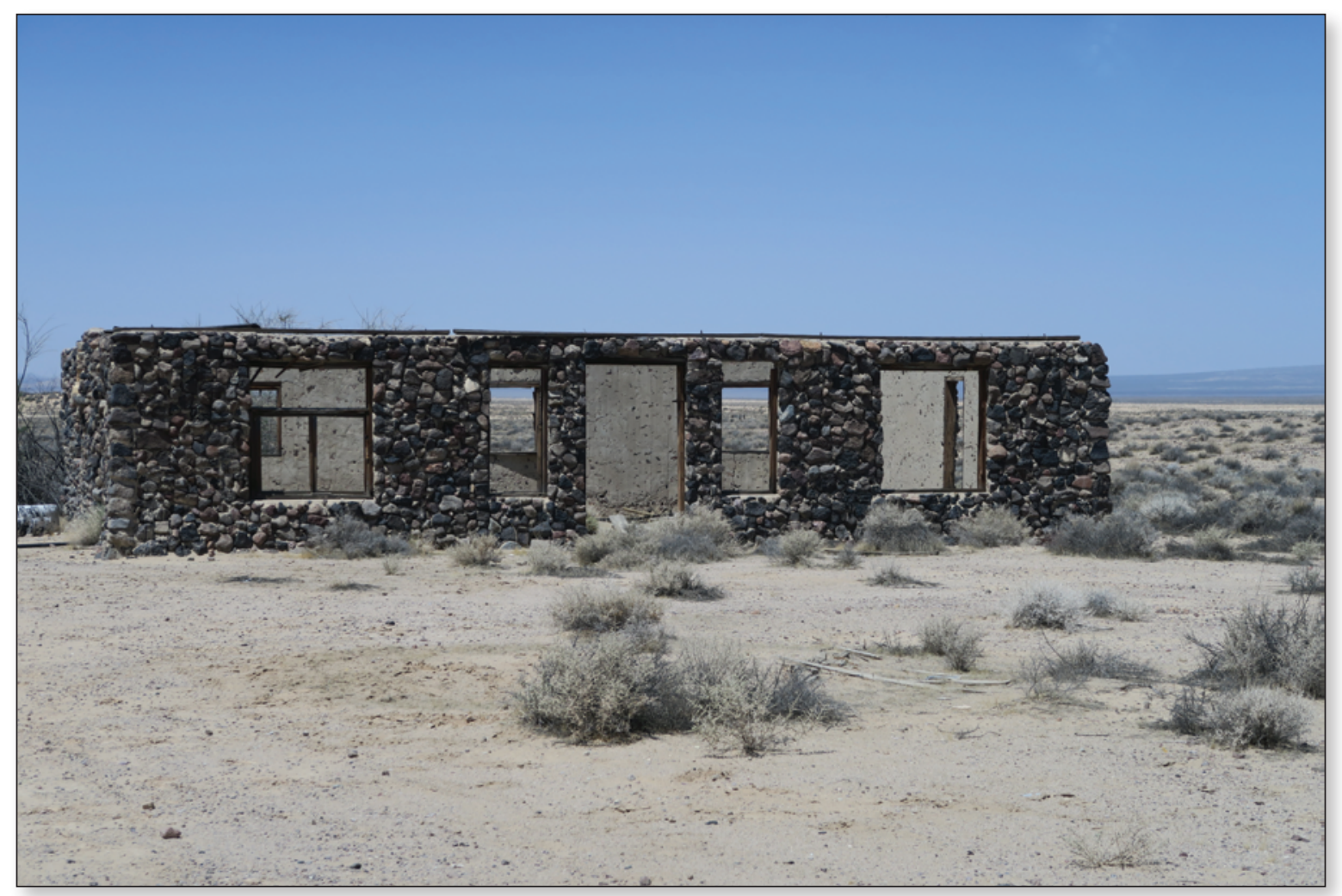




\title{
U.S. Department of the Interior DAVID BERNHARDT, Secretary
}

\author{
U.S. Geological Survey \\ James F. Reilly II, Director
}

\section{U.S. Geological Survey, Reston, Virginia: 2020}

For more information on the USGS - the Federal source for science about the Earth, its natural and living resources, natural hazards, and the environment-visit https://www.usgs.gov or call 1-888-ASK-USGS.

For an overview of USGS information products, including maps, imagery, and publications, visit https://store.usgs.gov.

Any use of trade, firm, or product names is for descriptive purposes only and does not imply endorsement by the U.S. Government.

Although this information product, for the most part, is in the public domain, it also may contain copyrighted materials as noted in the text. Permission to reproduce copyrighted items must be secured from the copyright owner.

Suggested citation:

Miller, D.M., Langenheim, V.E., and Haddon, E.K., 2020, Geologic map and borehole stratigraphy of Hinkley Valley and vicinity, San Bernardino County, California: U.S. Geological Survey Scientific Investigations Map 3458, 23 p., https://doi.org/10.3133/sim3458.

Associated data release:

Langenheim, V.E., Morita, A.Y., Martin, A.J., Jordan, J., and Haddon, E.K., 2019, Gravity data of the Hinkley area, southern California: U.S. Geological Survey data release, https://doi.org/10.5066/P9FV5LG5.

ISSN 2329-132X (online)

Cover photo. Abandoned home, southern Water Valley. Photograph by D.M. Miller (4/27/18). 


\section{Contents}

Introduction

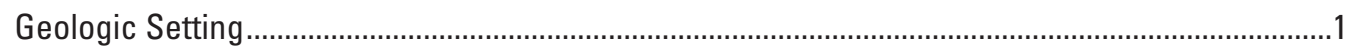

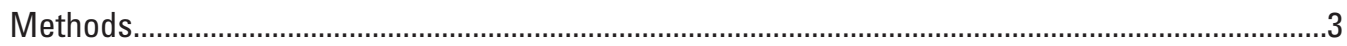

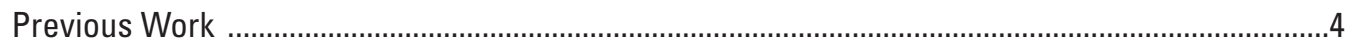

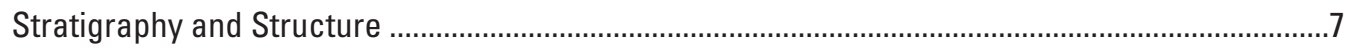

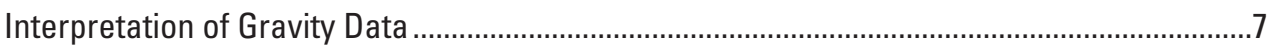

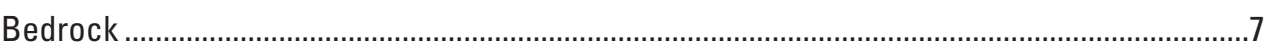

Miocene Basinal Deposits ..................................................................................................11

Pliocene and (or) Early Pleistocene Deposits ..........................................................................11

Quaternary Deposits..........................................................................................................

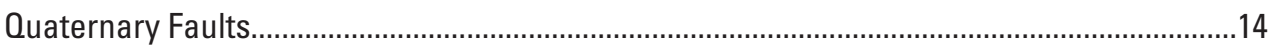

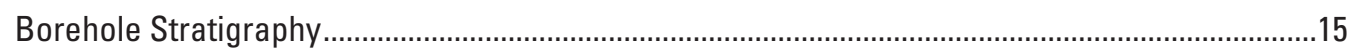

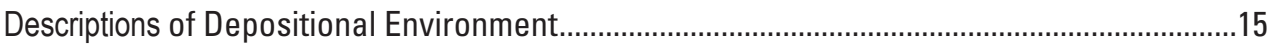

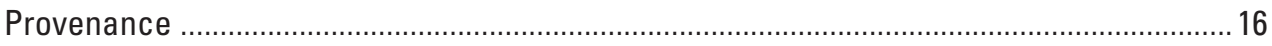

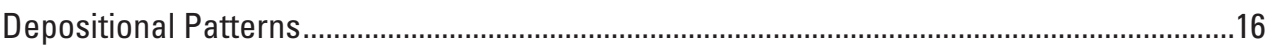

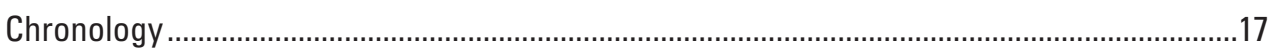

Deformation of Buried Strata near the Lockhart Fault Zone ..................................................17

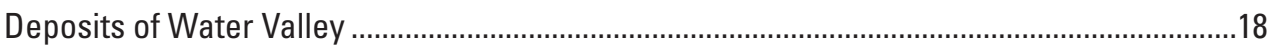

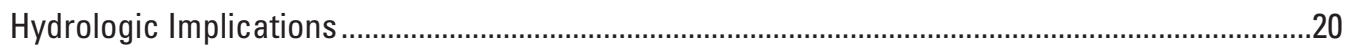

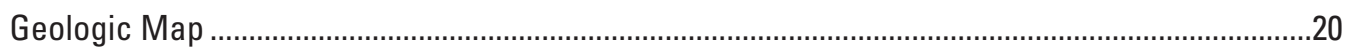

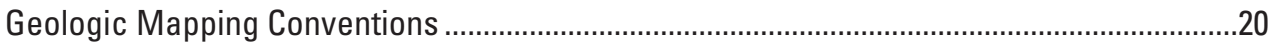

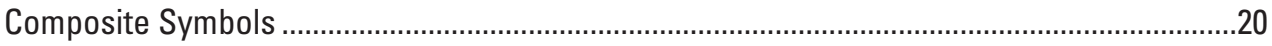

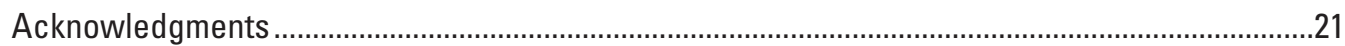

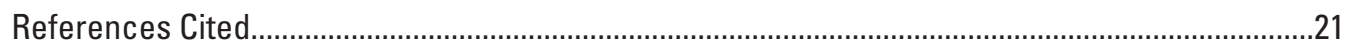

\section{Figures}

1. Simplified map showing the geology and geography of Hinkley Valley and vicinity, San Bernardino County, California ..............................................................................sheet 2

2. Map showing tectonic setting and major highways of the central Mojave Desert, southern California ................................................................................................

3. Map showing generalized geology of Hinkley Valley and vicinity, San Beranardino

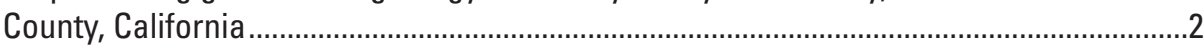

4. Geophysical maps of the Hinkley Valley area. A. Shaded-relief isostatic gravity map. $B$. Gravity contours on geologic map area. $C$. Depth to basement derived from gravity inversion

5. A. Cross section of Lockhart Fault Zone showing disruption of horizons detected in sediment core. $B$. Enlargement of geologic map area showing locations of wells used in cross section shown in $A$.

\section{Tables}

1. Elevation model parameters, Hinkley Valley and vicinity, San Bernardino County, California

2. Wavelength-dispersive $x$-ray fluorescence geochemistry of selected rocks in Hinkley Valley and vicinity, San Bernardino County, California

3. Inductively coupled plasma atomic emission spectroscopy (ICP-AES) geochemistry of selected rocks in Hinkley Valley and vicinity, San Bernardino County, California. https://doi.org/10.3133/sim3458 
4. Radiocarbon age data, Hinkley Valley and vicinity, San Bernardino Country, California.....6

5. Density-depth relation used in gravity inversion, Hinkley Valley and vicinity, San Bernardino County, California.

6. Criteria for interpretations of provenance, depositional environment, and age of core sediment, Hinkley Valley and vicinity, San Bernardino County, California.

7. Summary properties of sediment core from Hinkley Valley and vicinity, San Bernardino County, California..................................................................https://doi.org/10.3133/sim3458 


\title{
Geologic Map and Borehole Stratigraphy of Hinkley Valley and Vicinity, San Bernardino County, California
}

\author{
By David M. Miller, Victoria E. Langenheim, and Elizabeth K. Haddon
}

\section{Introduction}

Hinkley Valley, in the central to western Mojave Desert of southeastern California (fig. 1, map sheet 2), has a long historical record owing to its position as a crossroads for rail and road traffic and its position adjacent to the Mojave River. Subflow in the Mojave River provided groundwater recharge that maintained water consumption and demand by way of shallow wells for local agriculture (Thompson, 1929) in the valley. Its crossroads position led to construction of several power-transmission lines, pipeline, and communications cable routes that transect Hinkley Valley. One of these, a natural gas pipeline and its associated compressor station, was the locus of hexavalent chromium, $\mathrm{Cr}(\mathrm{VI})$, releases into, and consequent contamination of, groundwater (Izbicki and Groover, 2018). Understanding the movement and fate of the contaminants is a complex hydrologic and geochemical problem. Geologic mapping of the Hinkley Valley area provides framework elements for use in resolving this problem.

This report provides new information on surface and subsurface geology to better constrain the origin and geometry of hydrologically important deposits in the Hinkley Valley area and describes youthful faults that may control sediment distribution and groundwater flow. The geologic map (sheet 1) presents substantial new information on surficial geology, including Pliocene deposits, but does not contain significant new work on bedrock. Bedrock investigations were specific to identifying youthful faults and representative outcrops for rocks that were penetrated by boreholes in the valley. Special attention was placed on locating and describing youthful faults. In addition, we analyzed gravity data to (1) map horizontal gradients that we interpret to reflect long-term fault traces and to (2) estimate the depth to bedrock, which is defined as Miocene and older intrusive and metamorphic rocks for the purposes of this report.

The subsurface geology of Hinkley Valley was investigated by examining borehole sediment cores and rock encountered at the base of the sediment section. We analyzed the core to determine depositional environments, provenance, and age of the sediment that infilled the valley (Miller and others, 2018a).

Valleys, mountains, and basins in the Hinkley Valley area are topographically complex and incompletely named (fig. 1). The nearly flat floored Hinkley Valley slopes gently northward. It is framed by Mount General and the informally named "Hinkley hills" (southeast of Mount General) on the northeast and by Iron Mountain and Lynx Cat Mountain on the southwest, although breaks in the western mountains allow stream connections between Hinkley Valley and another valley to the west that is herein referred to as Hawes valley. At its south end, Hinkley Valley is traversed by the entrenched Mojave River, which passes east out of the valley past Barstow (fig. 1). North of Hinkley Valley, a few low hills (including Red Hill) separate the valley from a broad westsloping piedmont that is part of the physiographic Harper Basin (of which the Harper Lake playa is the center). The lower part of this piedmont, however, is referred to as Water Valley, although it is not a distinct valley. The name derives from groundwater sourced from subflow in the Mojave River, which caused shallow water and even artesian flow in Water Valley but not in other parts of the Harper Basin. When water filled the Harper Basin to form Pleistocene Lake Harper (Garcia and others, 2014), it not only submerged Water Valley but also northern Hinkley Valley.

\section{Geologic Setting}

The Hinkley Valley area lies in the central to western Mojave Desert, an area of conspicuous mountains separated by broad valleys (fig. 1, map sheet 2). The area is crossed by numerous strike-slip faults (fig. 2, map sheet 2). Bedrock of the area represents continental-margin marine sediments that were intruded and deformed during the Mesozoic, including thrusting of deep-water, outboard sediment eastward over cratonal sediment (Miller and others, 1995; Martin and Walker, 1991) accompanied by variable metamorphism. Mesozoic igneous plutons are variable in composition, ranging from diorite to leucocratic granite. Mesozoic deformation and metamorphism affected much of the Mesozoic intrusive rock (Fletcher and others, 2002), as well as pendants and wallrocks associated with the plutons. Wallrocks range from marble to quartzite and metavolcanic rocks (fig. 3).

Paleozoic and Mesozoic rocks in the Hinkley Valley area are overlain by complex Cenozoic sediments. The oldest are early Miocene deposits consisting of lacustrine to alluvial-fan, rock-avalanche, and volcanic rocks. These deposits are thought to occupy several small graben formed by coeval extension (Dokka, 1986; 


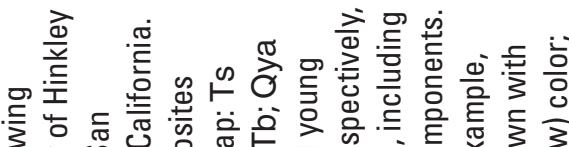

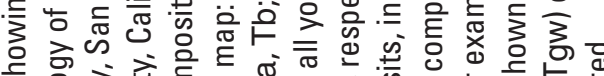

क

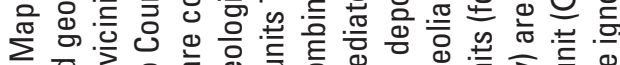

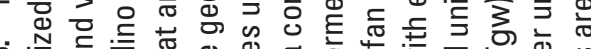

m.

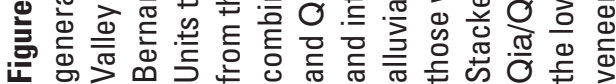
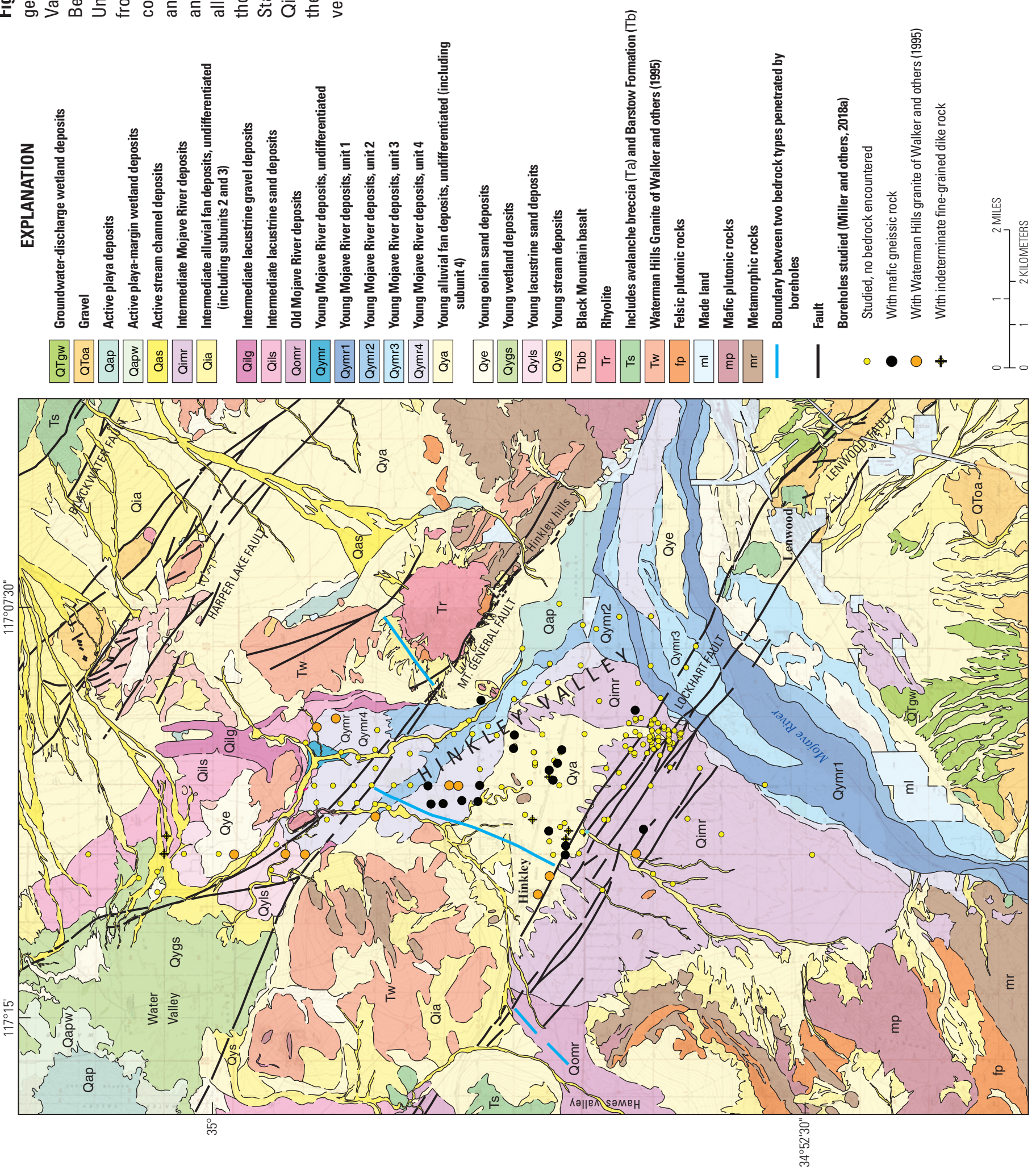
Fillmore and Walker, 1996). However, Anderson (2017) presented evidence that most of these basins did not form in an extensional setting. A widespread mass of 24-21 Ma granitic plutons and dikes, the Waterman Hills granite of Walker and others (1995), intruded and metamorphosed Mesozoic and older rocks (Walker and others, 1995). Mylonite developed in the roof of the intrusive mass was interpreted as forming along the mylonitic part of a detachment fault system (Fletcher and others, 1995; Glazner and others, 2002) of the central Mojave metamorphic core complex or above an expanding pluton (Anderson, 2017). The Barstow Formation (early and middle Miocene) overlies the early Miocene deposits and mainly consists of fine-grained deposits thought to represent sediments formed in shallow wide basins that postdated all extension (Fillmore and Walker, 1996).

The Eastern California Shear Zone was defined by Dokka and Travis (1990) as the part of the Mojave Desert across which active or very young strike-slip faults are known. It ranges from west of Barstow eastward to Baker, California (fig. 2), and crosscuts the early Miocene deposits and faults described above. It is a zone of active dextral shear associated with transpressional deformation inboard of the southern San Andreas Fault (fig. 2). This zone presently accommodates 20 to 25 percent of net shear between the Pacific and North American Plates and has been active for about 10 million years (Miller, 2017). Four faults of the Eastern California Shear Zone lie near Hinkley Valley: from west to east, the Helendale, Lockhart, Mount General, and Harper Lake Faults. The faults may not only influence the distribution of water-bearing sediment but may also influence groundwater flux across the fault zones.

Sediments that postdate the Barstow Formation indicate varied and changing paleogeography as the Eastern California Shear Zone faults evolved. Valleys were, in part, internally drained and, in part, drained by river systems that led to the Pacific coast (Cox and others, 2003). Broad folds and uplift of the Transverse Ranges disrupted these basins and river systems during the Pliocene, causing a shift to internal drainage and the development of typical alluvial fans and playas of many valleys.

\section{Methods}

We used standard geologic mapping methods to conduct detailed investigations of surficial materials with an emphasis on Hinkley Valley and parts of Water Valley. Mapping included digging shallow pits to examine sediment and soil profiles and evaluating outcrops and geomorphic features for the presence of youthful faults. Location control for mapping was by hand-held global positioning device, with an estimated 2-meter (2-m) horizontal accuracy. Interpretations of aerial photographs and high-resolution topography (over a limited part of the map area) were used to identify subtle geomorphic features that were then investigated in the field. The map units are classified on the basis of age and depositional process, with age provided in large measure by interpreting soil profiles and geomorphology of a deposit, similar to the approach outlined by Miller and others (2009). We provide a tabulation of all field stations in the accompanying GIS database.

Geologic mapping emphasized Quaternary and Pliocene deposits because, where saturated, they are important aquifers in the Mojave Desert (California Department of Water Resources, 2003). The mapping in this report revised previous reconnaissance and intermediate-scale mapping by Cox and others (2003) and Amoroso and Miller (2012). Older bedrock was studied in reconnaissance only, and the map reflects modest updates to prior mapping (Bowen, 1954; Dibblee, 1960a,b, 1968; Boettcher, 1990; Fletcher and Martin, 1998), as well as generalization to simplify its presentation.

Faults shown on the geologic map are known to be, or possibly are, Quaternary. Near Mount General, some faults in bedrock are included because they exhibit subhorizontal striae or are co-linear with mapped Quaternary faults. These faults may represent reactivated Miocene faults. Faults are classified on the map by certainty of their existence, rather than the common practice of classifying by certainty of location. The location attributes are complete in the database, but are not displayed by line symbols on the map. Mapping of faults was based on geomorphic criteria, as well as identification of lineaments such as alignments of plants and color changes.

We constructed high-resolution Structure-from-Motion topography (grid cell size of 11-18 centimeters [cm]) and orthorectified image mosaics (resolution approximately $10 \mathrm{~cm}$ ) to clarify the topographic expression of the Lockhart and Mount General Fault Zones. Surface models were built using customflown digital aerial photographs (resolution approximately $10 \mathrm{~cm}$ ) and evaluated using geographic information system software. The stereo overlap and sidelap between images are 60 and 25 percent, respectively. Three-dimensional (3-D) accuracy relies on a distribution of ground control points (GCPs) measured using campaign real-time kinematic global positioning system. Table 1 provides surface model parameters, including coverage area and the average standard deviation of the surface in 3-D based on the number of GCPs per model.

Sediment cores obtained and archived by Pacific Gas and Electric Company (PG\&E) and its consultants as part of groundwater remediation procedures were studied to determine provenance and depositional environment of the sediment. Archived sediment cores were collected by hollow-stem auger, with a few collected by sonic methods. Sediment cores (fig. 3) were studied by photographing and examining all available material in selected cores, which were generally in good condition. Several sediment attributes were described

Table 1. Elevation model parameters, Hinkley Valley and vicinity, San Bernardino County, California.

\begin{tabular}{|c|c|c|c|c|c|c|}
\hline Model fault zones & No. of images & Altitude (ft) & $\begin{array}{r}\text { Ground sample } \\
\text { distance }(\mathrm{cm})\end{array}$ & $\begin{array}{l}\text { Area } \\
\left(\mathbf{k m}^{2}\right)\end{array}$ & $\begin{array}{l}\text { No. of ground } \\
\text { control points }\end{array}$ & $\begin{array}{c}\text { Root mean } \\
\text { square error (m) }\end{array}$ \\
\hline Lockhart & 137 & $\sim 7,000$ & 9 & $\sim 72$ & 29 & $\sim 0.34$ \\
\hline Mount General & 151 & $\sim 5,000$ & 7.6 & $\sim 32$ & 13 & $\sim 0.68$ \\
\hline
\end{tabular}


including mineral composition, grain size and sorting, cementation and alteration, sedimentary structures, color, and paleontology. All work was done with hand lens and microscope. Preliminary results of this study were presented in Miller and others (2018a). For those boreholes that penetrated basement, bedrock type was studied and correlated to bedrock exposed in nearby mountains.

Whole-rock geochemical analyses (fig. 3) were conducted on rock samples to evaluate correlations of basalt flows and to identify plutonic and volcanic rocks. The analyses, which were performed under contract to the U.S. Geological Survey (USGS), included both wavelength-dispersive X-ray fluorescence (WDXRF) (table 2) and inductively coupled plasma atomic emission spectroscopy (ICP-AES) (table 3, https://doi.org/10.3133/sim3458). Samples of the freshest rock available were collected and trimmed to avoid areas of alteration, varnish, and weathering, except in one case that was included to compare chemistry for a highly vesiculated basalt with a non-vesiculated basalt.

Radiocarbon dating on charred wood from soil pits was conducted by Beta Analytic, Inc., using a pretreatment by a standard alkali/acid/alkali method. Radiocarbon dates on whole-shell samples of the freshwater mussel Anodonta californiensis, which inhabits the nearshore in lakes and rivers, provides approximate water-depth information (Ingram, 1948). Samples were processed at the ${ }^{14} \mathrm{C}$ laboratory of the U.S. Geological Survey in Reston, Virginia. Shells were isolated by soaking samples in a weak Calgon solution for several hours. The shells were sonicated in distilled water for $1 \mathrm{hr}$ to remove additional surface sediment. Radiocarbon analyses were calibrated using Intcal13 (Calib 7.1, Reimer and others, 2013). The calibrated ages and uncertainties shown in table 4 are the median value and $2 \sigma$ error range. Calibrated ages in years before present (B.P.; by convention, years before 1950) are reported as cal yr. Calibrated ages in thousands of years B.P. are reported as cal ka.

Tephrochronological analysis of volcanic glass in outcrop and core samples was used to estimate the depositional age through statistical comparison of glass composition with previously analyzed tuffs in a large database maintained by the USGS Tephrochronology Project in Menlo Park, California. Glass shards used for chemical analysis were separated from the 200- to 100-mesh-size fraction ( 75 to 150 microns, respectively) of each sample. Results summarized in this report are from Miller and others (2018a).

Gravity data consisting of 785 new measurements were collected to augment existing data in the map area (Tang and Ponce, 1982; Morin, 1995; Subsurface Surveys, 1990); both previously collected and new data are available in Langenheim and others (2019). Data were processed to isostatic gravity anomalies using a reduction density of 2,670 kilograms per cubic meter $\left(\mathrm{kg} / \mathrm{m}^{3}\right)$ and included Earth-tide, instrument drift, free-air, Bouguer, latitude, curvature, and terrain corrections (Telford and others, 1976). An isostatic correction using a sea-level crustal thickness of 25 kilometers $(\mathrm{km})$ and a mantle-crust density contrast of $400 \mathrm{~kg} / \mathrm{m}^{3}$ was applied to the gravity data to remove the long-wavelength gravitational effect of isostatic compensation of the crust from topographic loading. Data were gridded at a spacing of $250 \mathrm{~m}$ using a minimum curvature algorithm (Briggs, 1974). The resulting gravity field, which is termed the isostatic residual gravity anomaly, reflects density variations in the upper and middle crust.
An important density contrast in the upper crust is between dense basement rocks, defined in this report as Miocene and older intrusive and metamorphic rocks, and overlying, less dense basin fill. The location of steeply dipping or vertical faults or contacts that juxtapose rocks of differing density coincides with the maximum change in the gravity anomaly values, also known as the maximum horizontal gravity gradient. We use a computer algorithm (Cordell and Grauch, 1985; Blakely and Simpson, 1986) to locate horizontal gravity gradient maxima within the isostatic gravity grid. To estimate the depth to basement, we use the technique of Jachens and Moring (1990), modified to include independent constraints such as depths known from wells. This method separates the gravity field into a component caused by variations in the density of the basement rocks ("basement gravity") and a component caused by variations in basin fill ("basin gravity"). A first approximation of the basement gravity field is calculated using only those measurements made on basement outcrops. The basin gravity is then inverted to basin thickness, assuming a function where density varies as a function of depth (table 5). The gravity effect of the less dense basin extends out beyond the basin-basement contact, resulting in an underestimation of the basement gravity field. As a result, the inversion process is iterated to remove the gravitational effect of the basin fill until the model converges onto a solution, usually within six iterations.

\section{Previous Work}

Comprehensive geologic mapping by Bowen (1954) and Dibblee (1960a,b, 1968) described the framework of mountain ranges consisting mainly of granitic, metamorphic, and volcanic rocks. This mapping also portrayed uplifted youthful gravels in the Lenwood area and between Iron and Lynx Cat Mountains. Dibblee also recognized shorelines associated with ancient lakes in Harper Basin, as well as youthful northwest-striking strikeslip faults (Dibblee, 1961). Less emphasis was placed on valleyfloor deposits and the development of the Mojave River system.

Gravity methods have long been used to estimate the thickness of Cenozoic basin deposits in the Mojave Desert, starting with the work of Mabey (1960). That study of the western Mojave Desert revealed gravity lows and recognized that these lows reflected basins filled with low-density Cenozoic deposits. In the vicinity of the map area, Mabey (1960) suggested that the gravity low attributed to the Barstow Syncline was offset by the Harper Lake Fault, discussed a major gravity low west of Iron and Lynx Cat Mountains as reflecting a trough as deep as $1.5 \mathrm{~km}$, and pointed out a prominent east-west gravity gradient between Harper Lake and Hinkley Valley. Saltus and Jachens (1995) modeled the depth of basins throughout the Basin and Range using the method of Jachens and Moring (1990) with grids of a 2-km cell size. Jachens and others (2002) refined this inversion for the Mojave Desert using a density-depth function validated by wells that penetrated pre-Cenozoic basement. Another application of this technique was applied to the Fort Irwin region, mostly to the northeast of the map area, by Jachens and Langenheim (2014), using a 250-m grid and independent constraints of depth to pre-Cenozoic basement. A companion paper (Langenheim and Jachens, 2014) to the Jachens and Langenheim (2014) study also 


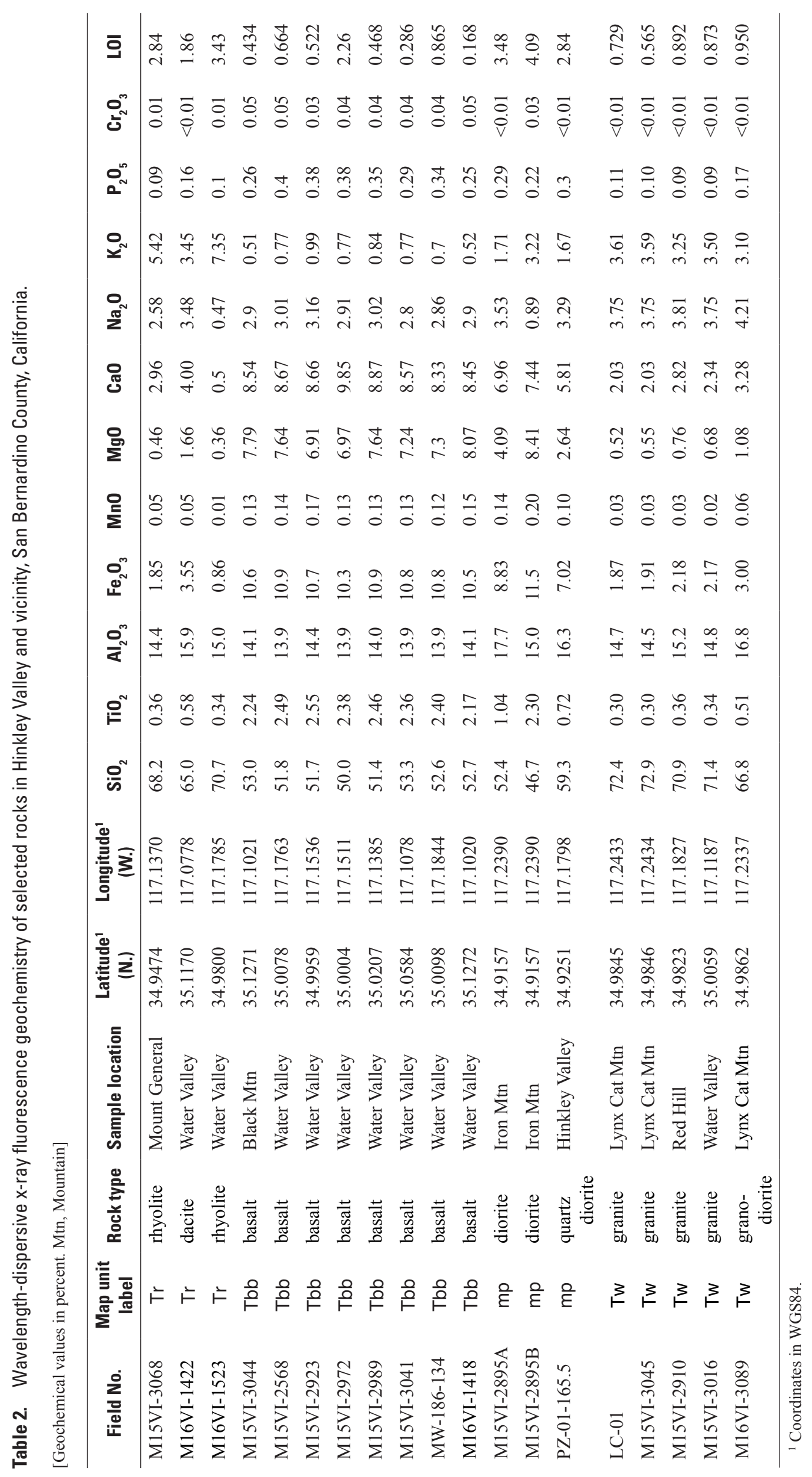


Table 4. Radiocarbon age data, Hinkley Valley and vicinity, San Bernardino Country, California.

\begin{tabular}{|c|c|c|c|c|c|c|c|c|c|c|c|}
\hline Lab No. ${ }^{1}$ & Sample ID & $\begin{array}{l}\text { Map } \\
\text { unit }\end{array}$ & Material & Easting $^{2}$ & Northing $^{2}$ & $\delta^{13} \mathrm{C}$ & ${ }^{14} \mathrm{CAge}^{3}$ & $\pm^{4}$ & Dated on & $\begin{array}{l}\text { Intcal135 } \\
\text { minimum }\end{array}$ & $\begin{array}{l}\text { Intcal135 } \\
\text { maximum }\end{array}$ \\
\hline WW10869 & Red Hill & Qils & Anodonta & 484662 & 3870929 & 0.5 & $30,940 \mathrm{yr}$ & 230 & $05 / 17 / 16$ & 34,380 & 35,360 \\
\hline 454616 & M16VI-3142 & Qygss & Charred wood & 479492 & 3875547 & -24.9 & $1,650 \mathrm{yr}$ & 30 & $01 / 9 / 17$ & 1,610 & 1,625 \\
\hline 495441 & M18VI-386 & Qymr & Charred wood & 485043 & 3870481 & -25.7 & $1,820 \mathrm{yr}$ & 30 & $05 / 29 / 18$ & 1,525 & 1,610 \\
\hline
\end{tabular}

\footnotetext{
${ }^{1} \mathrm{WW}$ sample was processed at the ${ }^{14} \mathrm{C}$ laboratory of the U.S. Geological Survey in Reston, Virginia. Other results obtained by Beta Analytic, Inc.

${ }^{2}$ Location information in Universal Transverse Mercator (UTM) projection, zone 11; World Geodetic System 84 (WGS84) datum.

${ }^{3} \mathrm{The}{ }^{14} \mathrm{C}$ age is in radiocarbon years before present using the Libby half life of 5,568 years.

${ }^{4}$ Uncertainty $( \pm)$ is given at 1 standard deviation.

${ }^{5}$ Intcal (Reimer and others, 2013) values calibrated at 2 standard deviations.
}

compiled and analyzed aeromagnetic data of the Fort Irwin region to ascertain structural grain, map concealed faults, and point out long-term fault offset by correlating offset magnetic features.

Recent, concerted study of the mountains in the Hinkley Valley area placed emphasis on the ages and structural characteristics of bedrock, structural evolution of the area, modes of intrusion of granite, and extrusive rocks in sedimentary basins and the tectonic setting of those basins. These studies, summarized by Glazner and others (2002), applied the metamorphiccore-complex concept to the area and proposed that both ductile and brittle tectonic extension during the early Miocene affected rocks in the area. By this hypothesis, an important structural boundary — a detachment fault — is buried near the Lockhart Fault Zone in Hinkley Valley. More recently, Anderson (2017) questioned the magnitude of extension and mode of granite intrusion and basin formation as interpreted by the earlier work, but supported the presence and location of the detachment fault.

Surficial geology of Pliocene to modern deposits has been mapped and studied by several workers. Cox and others (2003) studied the deposits associated with the ancestral and modern Mojave River, including brief study of the southern Hinkley Valley area. Amoroso and Miller (2012) mapped the northern Harper Basin area at intermediate scale. Meek (1999) and Garcia and others (2014) studied lacustrine deposits in the northern Hinkley Valley. Miller and others (2018a) established that most of the Hinkley Valley deposits were deposited by the ancestral Mojave River and described the architecture of deposits, as well as the character of faults cutting those deposits.

Study of youthful faults included recognition that the faults of the central Mojave Desert behave as a wide continental shear zone named the Eastern California Shear Zone by Dokka and Travis (1990). Study of the Harper Lake Fault north of the map area by Glazner and Bartley (1994) identified pre- and post-Pliocene folds and faults that were interpreted as transpressional. The faults of Hinkley Valley received little careful study before recent work by the U.S. Geological Survey, summarized by Miller and others (2007) as an inventory of active and recently active faults of the northern Mojave Desert. That study identified youthful rupture of the Mount General and Harper Lake Faults. Amoroso and Miller (2012) argued that slip on dextral (right-lateral) faults transfers southwest from the Calico and Blackwater Faults to the Harper Lake Fault. Long-term offsets for the Harper Lake and Mount General Faults were estimated by mismatched geophysical features by Jachens and others (2002), Jachens and Langenheim (2014), and Langenheim and Jachens (2014). Andrew and Walker (2017) reiterated these results and added geologic analysis for the Lockhart Fault, which to date had not been recognized in Hinkley Valley.

Cox and others (2003) developed the following model for the Pliocene and Pleistocene history of the region that includes Hinkley Valley. Sediments that postdate the Miocene Barstow Formation indicate varied and changing paleogeography as the Eastern California Shear Zone faults evolved (fig. 2). Pliocene valleys were internally drained to form lake basins and a few river systems drained externally from the Mojave Desert region to the Pacific coast. The growth of broad transpressional folds and uplift of the Transverse Ranges disrupted these basin and river systems. By the late Pliocene, the rise of the Transverse Ranges caused a shift to internal drainage and created alluvial fans, braided streams, lakes, and marshes in Victorville valley. A clastic wedge was shed north from the rising San Bernardino Mountains into the Phelan Basin and, ultimately, into the Victorville Basin. As the wedge advanced, it constrained lake and marsh environments at its north tip against the former south-draining topography, resulting in a distinctive tripartite stratigraphic sequence of (1) basal south-flowing stream deposits sourced from the central Mojave Desert, (2) overlain by wetland and lacustrine deposits, in turn (3) overlain by north-flowing braided stream deposits derived from the Transverse Ranges. The uppermost unit was termed the ancestral Mojave River deposits by Cox and others (2003), who argued that the deposits first "escaped," or were transported from, the Victorville Basin 575-475 ka.

Table 5. Density-depth relation used in gravity inversion, Hinkley Valley and vicinity, San Bernardino County, California.

\begin{tabular}{cc}
\hline Depth range in meters & Density contrast in $\mathbf{~ g ~} / \mathbf{m}^{\mathbf{3}}$ \\
\hline $0-100$ & -700 \\
$100-200$ & -600 \\
$>200$ & -450 \\
\hline
\end{tabular}




\section{Stratigraphy and Structure}

We describe below results important for groundwater occurrence and movement, the basis for age assignments for several map units, and significant map relations (including youthful faults). Complete descriptions of all map units are provided in the Description of Map Units (sheet 1).

\section{Interpretation of Gravity Data}

Physical properties of the bedrock, defined here to be Miocene intrusive and pre-Cenozoic rocks, give rise to characteristic gravity anomalies. In general, bedrock exposures coincide with gravity highs that bisect the map area (fig. $4 A$ ), with the highest values measured over significant outcrops of mafic plutonic rocks at Iron Mountain and Hinkley hills (fig. 4B). Significant gravity lows are present over the northern and southern parts of the map area, where Cenozoic basin deposits are extensively exposed. Much of this variation can be attributed to thicker low-density basin fill, but variations in basement density may also contribute to the isostatic gravity field. A significant gravity gradient delineated by measurements, particularly on Waterman Hills granite such as in Lynx Cat Mountain (fig. 4B), indicate density variations in the basement rocks that are not readily explained by the surface geology. This east-northeast-trending gravity gradient (where not offset by younger dextral faults) is also mirrored by aeromagnetic anomalies (Jachens and others, 2002). The trend of these anomalies is similar to strike of steeply dipping limbs of folds in pre-Cenozoic rocks that the Miocene granite intruded (Andrew and Walker, 2017), further supporting the argument that these gradients are sourced in pre-Cenozoic rocks not exposed at the surface. Regardless of the source of these gradients, strikeslip faults offset them and indicate the location of fault strands that have significant $(>1 \mathrm{~km})$ displacement. On the basis of detailed aeromagnetic data, Jachens and others (2002) estimated $5 \mathrm{~km}$ and $3.1 \mathrm{~km}$ of right-lateral displacement on the Harper Lake and Mount General Faults, respectively. They did not estimate offset on the Lockhart Fault because of the lack of detailed aeromagnetic data. Offsets of gravity gradients add to the information from the aeromagnetic study. The significant gradient on the northwest margin of the central gravity high (fig. $4 B$ ) is offset by distances consistent with the estimates from the aeromagnetic data, as well as with projections of various geologic features across these faults (Andrew and Walker, 2017). The northwest margin of the southern gravity low appears to be offset right-laterally by the Lockhart Fault, with $\sim 3 \mathrm{~km}$ of estimated offset. This is considerably more than the $1.0 \pm 0.7 \mathrm{~km}$ inferred by Andrew and Walker (2017) for the section of the Lockhart Fault $\sim 10 \mathrm{~km}$ to the northwest.

Cenozoic basin fill generally is marked by gravity lows and generally is thickest under modern valleys. An exception is Hinkley Valley, which has isostatic-gravity-anomaly values of $-10 \mathrm{mGal}$ or higher. Not only does this indicate that the basin fill is thin, but that it must also be underlain by relatively dense basement. All of these observations indicate the necessity of explicitly taking into account variations in basement gravity in the gravity inversion, as described under the Methods section. The results of the inversion, constrained by drill holes that intercept basement, indicate that basin fill beneath northern Hinkley Valley is generally less than $120 \mathrm{~m}$ (dark blue contour in fig. $4 C$ ) in thickness. In much of western Hinkley Valley, basin fill is modeled as less than $50 \mathrm{~m}$ thick and several wells penetrate bedrock. Such thin fill in this area is supported by the presence of isolated, small hills of bedrock that have not been buried by valley deposits. The inversion reveals considerably thicker basin fill in southern Hinkley Valley near the Mojave River. Most of the fill in that basin depocenter (the western end of the Barstow Syncline of Mabey, 1960) is likely composed of Barstow Formation, as suggested by a pair of outcrops within the Lockhart Fault Zone near Lenwood. Localized thicker pockets of fill are located within that fault zone. Another depression in the basement surface lies beneath Water Valley and areas to the east, with elongate thicker pockets of basin fill within the Harper Lake Fault Zone. Most of the basin deposits are likely to consist of Barstow Formation.

Given that the thickness of basin fill is a component for groundwater-flow models of Hinkley Valley, it is important to remember some of the assumptions and possible shortcomings of the thickness of basin fill estimated by the gravity inversion. The inversion assumes no lateral density variations within the basin fill. As a result, thickness of basin fill that is denser (generally coarser grained) than the assumed density-depth function will be underestimated and thickness of basin fill that is less dense (generally finer grained) will be overestimated. Although our choice of density-depth relation is informed by comparison of estimated basin thickness with well control, densities of basin-filling deposits below that well control are poorly known and the details of the deeper parts of the basin model should be viewed accordingly. Uncertainty in the basement gravity field is important in areas where there are no gravity measurements on basement, no well control, or no independent estimates of basement depth from seismic or electrical techniques. For example, we did not include a gravity measurement on Waterman Hills granite that forms a small hill in the Harper Lake Fault Zone, because it may not be representative of the basement-gravity field. Even in well-constrained areas, such as parts of Hinkley Valley, uncertainties in the accuracy of the gravity anomaly value, particularly because of inaccuracy in elevation and terrain correction, suggest that the estimate of basin thickness is accurate to about $15-30 \mathrm{~m}$.

\section{Bedrock}

Mountains adjacent to Hinkley Valley expose four main rock sequences: (1) Precambrian and Paleozoic strata that are metamorphosed to a high grade, (2) mafic to felsic, generally foliated, Mesozoic granitoid, (3) early Miocene granite to granodiorite (Waterman Hills granite of Walker and others, 1995), and (4) rhyolite and dacite masses that are both intrusive and extrusive (Boettcher, 1990; Fletcher and Martin, 1998). With few exceptions, wells we studied that penetrate bedrock in Hinkley Valley retrieved two rock types: (1) variably deformed biotite granite similar to the Waterman Hills granite exposed in Lynx Cat Mountain and (2) gneissic biotite-hornblende quartz monzodiorite ( $\sim 58$ percent $\mathrm{SiO}_{2}$ ) similar to minor exposures 


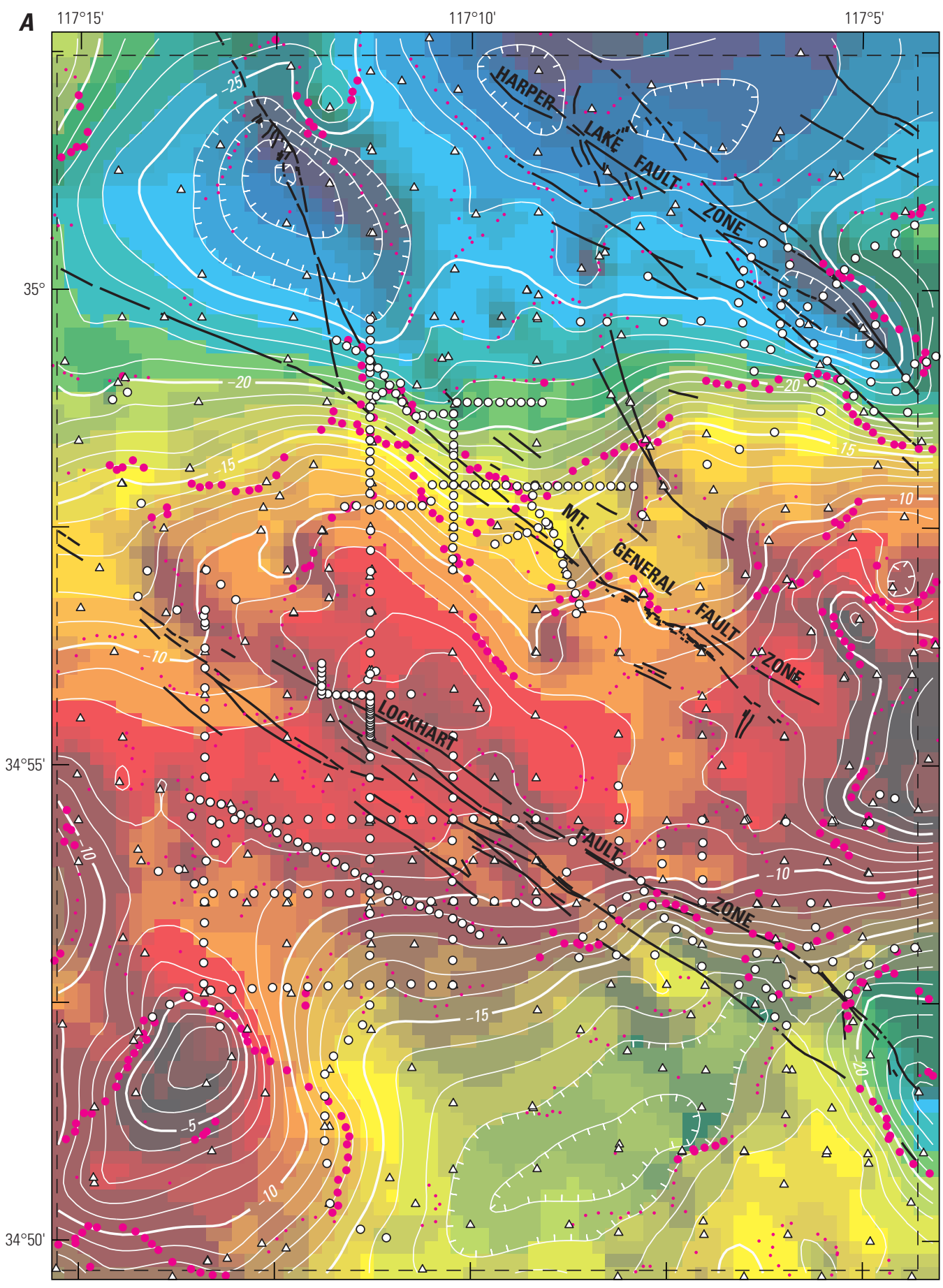

\section{EXPLANATION}

Color contour-Contour interval $2 \mathrm{mGa}$

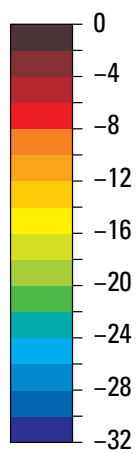

- -10- Gravity contour-Contour interval $1 \mathrm{mGal}$

- - Extent of geologic map

__ Faults from this study

Gravity measurements

$\Delta \quad$ Previously collected

○ Newly collected

Maximum horizontal gravity gradients that occur over contacts between rocks of different density

- Smaller gradients

- Larger gradients

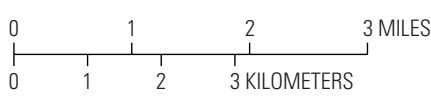

Figure 4 (pages 8-10). Geophysical maps of Hinkley Valley and vicinity, San Bernardino County, California. A. Shaded-relief isostatic gravity map. $B$. Gravity contours on geologic map area. C. Depth to basement derived from gravity inversion. 


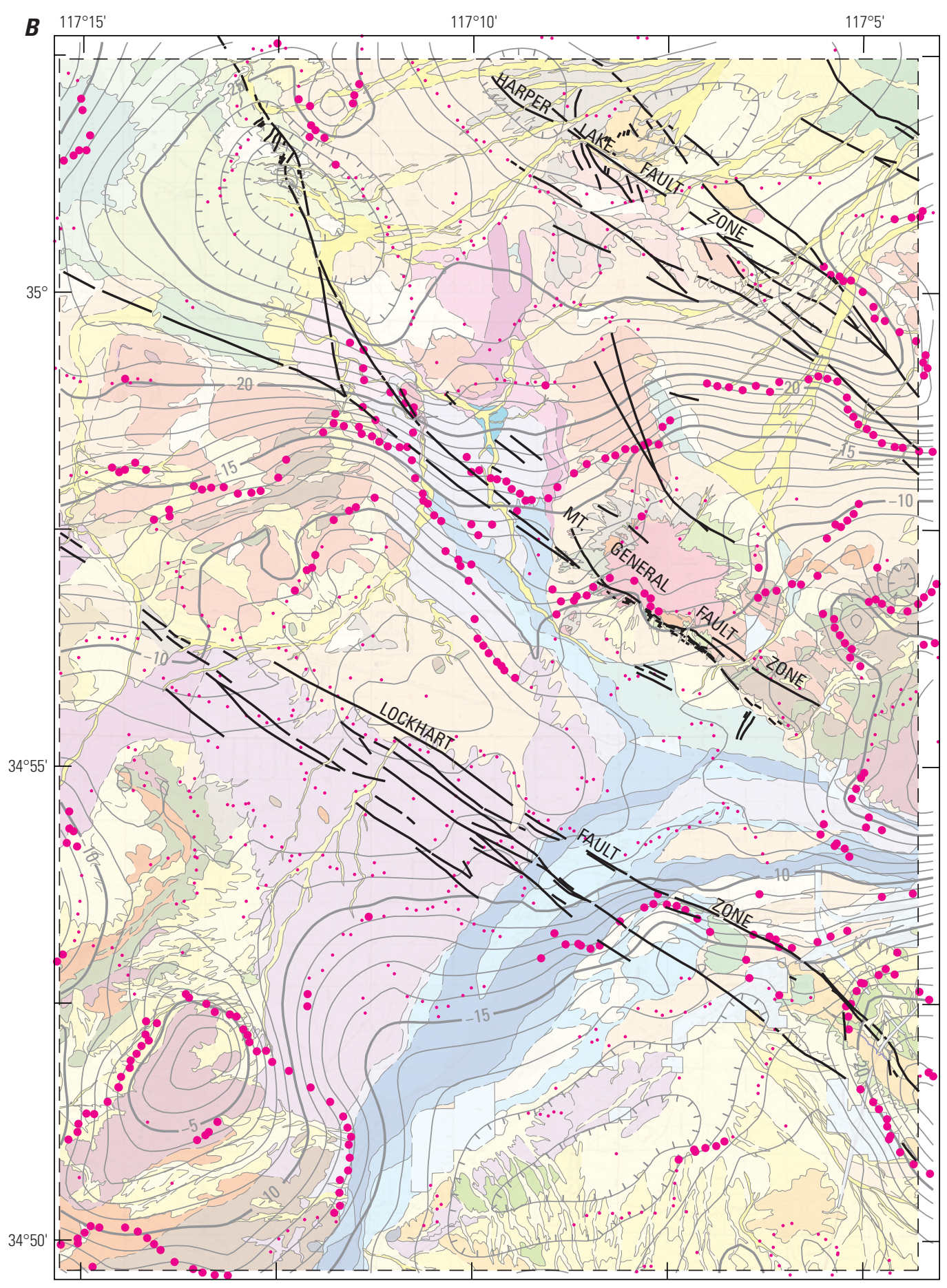

\section{EXPLANATION}

- - Extent of geologic map

Gravity contours-Contour interval $1 \mathrm{mGal}$

Faults from this study

Maximum horizontal gravity gradients that occur over contacts between rocks of different density

- Smaller gradients

- Larger gradients

Figure 4 (pages 8-10). Continued 


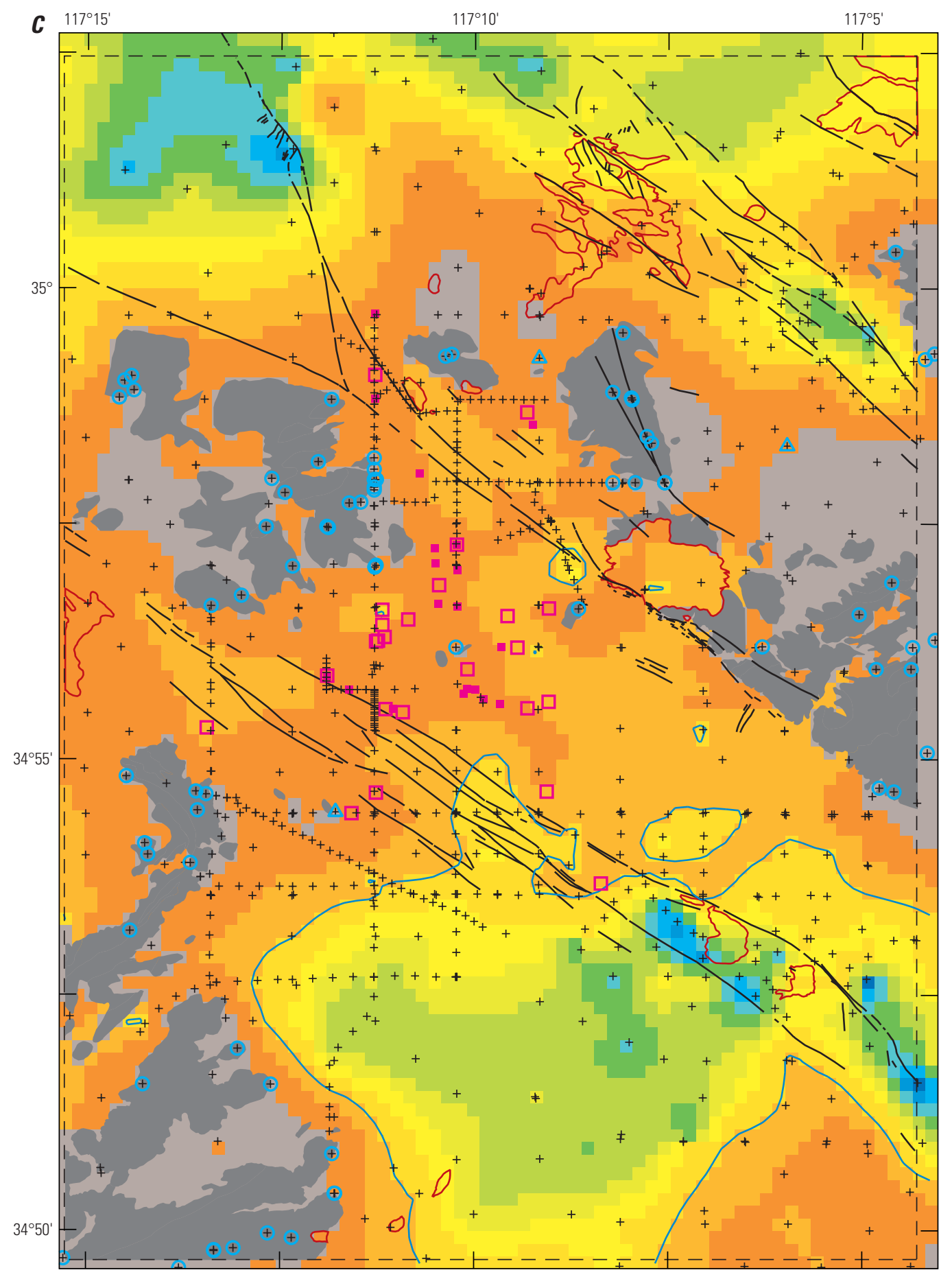

\section{EXPLANATION}

Depth to basement, in meters

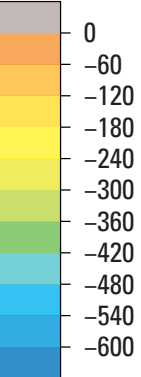

Basement outcrop

- - Boundary of Hinkley Valley map area

- Outcrops of Cenozoic volcanic rocks

_ Faults

Shallow bedrock shelf of central Hinkley Valley

+ Gravity measurement

$\oplus \quad$ On basement

4 Near basement used in inversion

Well

$\square \quad$ Intercepts basement

- Did not intercept basement and provide minimum constraint on basement

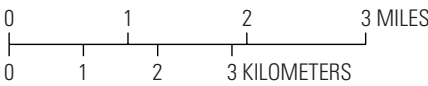

Figure 4 (pages 8-10). Continued 
in the north end of Iron Mountain that were mapped both as muscovite-biotite granite (unit bg) and as gabbro by Boettcher (1990). The boundary between these two rock types at depth in Hinkley Valley is shown as a blue line in figure 3, as are wells constraining the location of the line. The Waterman Hills granite is found west of the gneissic rocks. A few wells bottomed in felsic dike rock and Tertiary(?) sandstone.

The Waterman Hills granite of Walker and others (1995) ranges in composition from biotite granite to biotite \pm hornblende granodiorite (tables 2, 3 [https://doi.org/10.3133/sim3458]) and generally contains $10-15$ percent mafic minerals. Subtle variations in composition are evident in Lynx Cat Mountain, and more pronounced variations over shorter distances of a few tens of meters are evident at Mount General and in hills north of Mount General. Anderson (2017) proposed that the variation in composition at and near Mount General was caused by dike-on-dike intrusions that expanded the pluton laterally. In these locations the rock possesses a very fine grained groundmass suggesting rapid cooling in a shallow crustal setting.

Rhyolite and dacite, present as dikes, sills, and extrusive bodies hundreds of meters wide, exist in both the footwall and hanging wall of the Waterman Hills detachment fault (Fletcher and Martin, 1998). The rocks are generally altered, but relatively fresh rock exposed in a few locations is gray with $\sim 10$ percent feldspar + biotite \pm quartz crystals. Geochemical analyses confirm that the rock ranges in composition from rhyolite to dacite (tables 2, 3 [https://doi.org/10.3133/sim3458]). At Mount General, we follow previous mapping and show a large mass of unit $\mathrm{Tr}$, although beds of conglomerate and breccia indicate that some sedimentary units are present (N. Onderdonk, California State University Long Beach, written commun., 2018).

\section{Miocene Basinal Deposits}

Miocene continental sedimentary and volcanic rocks are widespread in the Barstow area. They are divided into two groups: an early synorogenic set considered to be associated with extensional basins (Dokka, 1986, 1989; Glazner and others, 2002; Fillmore and Walker, 1996; Fletcher and others, 1995), and an overlying postorogenic unit. The early set of units is composed of the early Miocene Jackhammer and Pickhandle Formations, which comprise conglomerate, sandstone, limestone, and volcanic rocks that crop out primarily east of the map area (fig. 3). The rock avalanche deposits (unit Ta) north of Iron Mountain probably belong to this set of units. These rock avalanche deposits occur as nearly monolithologic sheets of intensely shattered rocks similar to those in outcrop in the northern Iron Mountain area: marble, gneiss, and felsic and mafic plutonic rocks. The sheets display jigsaw fracture textures. Granite-boulder conglomerate overlies the avalanche sheets in the north and occurs between sheets in a few places. A distinctive gravel deposit (unit Tg) that crops out near Johnstons Corner (former village of JC) along the Mojave River may also belong to the early synorogenic unit. The gravel consists of clasts of gneissic intrusive rocks similar to the rocks that crop out in the southern Iron Mountain area. It appears to lie unconformably on the metamorphic rocks of Iron Mountain.
The early and middle Miocene Barstow Formation (MacFadden and others, 1990) mainly consists of fine-grained sandstone, siltstone, shale, and limestone thought to represent deposition in a shallow, wide basin that postdated all extension (Fillmore and Walker, 1996). These rocks are exposed in the Mud Hills in the northeastern corner of the map (sheet 1). We map coarse sandstone, limestone, and minor volcanic rocks near Lenwood as the Barstow Formation. The outcrops near Lenwood lack the fine-grained sequences of the type Barstow Formation.

\section{Pliocene and (or) Early Pleistocene Deposits}

Deposits that overlie the early to middle Miocene Barstow Formation are widespread but generally little studied and poorly dated. As a result, they are grouped into a Pliocene-Pleistocene (unit QToa) category of chiefly alluvial-fan deposits. Deposits may range from latest Miocene to middle Pleistocene. Near Barstow, they lie unconformably on the Barstow Formation (Bowen, 1954; Dibblee, 1960a); in Water Valley, they lie on early Miocene granite; south of the Mojave River near Johnstons Corner, they are greater than $40 \mathrm{~m}$ thick and lie on Mesozoic metavolcanic rocks (Dibblee, 1960a). Hills along the Harper Lake Fault expose widespread Pliocene basalt (unit Tbb). We identified two ash beds in deposits of unit QToa that overlie the basalt in eastern Water Valley. One was correlated with the tuff of Blind Spring, a 2.2-Ma ash bed in Death Valley (Knott and others, 2005). The second ash bed, apparently $\sim 10-20 \mathrm{~m}$ lower in the section, best correlates with the $\sim 12$ Ma tuff of Ibex Hollow. One of the two ash beds must be erroneously correlated. The deposits contain clasts of the Pickhandle and Barstow Formations, as well as a few clasts of Pliocene basalt, and represent an alluvial-fan depositional environment. The age of $\sim 12 \mathrm{Ma}$ is therefore unlikely, and $\mathrm{a} \sim 2.2 \mathrm{Ma}$ is the best age for these QToa deposits.

Hills from Lenwood west to Johnstons Corner expose a thick sequence of alluvial-fan deposits (unit QToa) with a groundwaterdischarge-deposit interval (unit QTgw) in its upper part. Distinctive clasts derived from the Sidewinder Volcanics indicate stream flow from the south. The Sidewinder Volcanics clasts increase westward in the deposit. Southeast of Lenwood, Cox and others (2003) identified two ash beds in unit QToa deposits that we interpret as ancient groundwater discharge deposits (unit QTgw) on the basis of abundant $\mathrm{CaCO}_{3}$, fine grain size, and abundant root casts. The ash beds (sample TC-2 in Cox and others, 2003) had identical shards, which were assigned a probable correlation to a Honey Lake ash bed and, thus, may be 2.5-2.06 Ma. Westward, near Johnstons Corner, opal layers form the outermost rinds on $\mathrm{CaCO}_{3}$-rich beds of unit QTgw in the upper part of a thick unit QToa gravel sequence. A sample of opal yielded a U-Pb age of $2.42 \pm 0.36 \mathrm{Ma}$ (K. Maher, Stanford University, written commun., 2008). The similarity of the ash and U-Pb ages may indicate that wetland conditions were widespread at about 2.4 Ma. Near Lenwood, the unit QToa deposits lie unconformably on folded rocks of the Barstow Formation (Dibblee, 1960a). The older rocks dip steeply to moderately, whereas, the younger deposits dip gently northeastward except where folded to gentle southwest dips by the local Lenwood anticline. Unit QToa deposits near Johnstons Corner dip gently north, apparently as a result of broad folds. 
The previously unnamed basalt of Black Mountain is informally named herein for extensive exposures at Black Mountain (fig. 1) north of the map area, which is thought to be the eruptive center (Glazner and Bartley, 1994). Distinctive mineralogy, texture, and chemistry permit correlation of basalt from Black Mountain to isolated exposures in Water Valley and to basalt recovered in wells near Hinkley Road in Water Valley. The basalt is very dark gray to dark brown and typically is crystal rich with plagioclase, olivine, and pyroxene phenocrysts. It forms stacked sets of lava flows in sequences of as many as three flows in Water Valley and has a maximum total thickness of $\sim 15 \mathrm{~m}$. Degassing tubes and columnar joints are common features. Geochemistry features are elevated $\mathrm{SiO}_{2}$ of 53 percent, low $\mathrm{CaO}$ at 8.5 percent, and high $\mathrm{MgO}$ at $\sim 8.0$ percent (tables 2, 3 [https://doi.org/10.3133/sim3458]). The ${ }^{40} \mathrm{Ar} /{ }^{39} \mathrm{Ar}$ dating by Oskin and Iriondo (2004) was performed on glass matrix in three samples from three separate flows collected northeast of Black Mountain, where a thicker section is present. The ages ranged from $3.77 \pm 0.11 \mathrm{Ma}$ to $3.56 \pm 0.08 \mathrm{Ma}$ (uncertainty reported at $2 \sigma$ ); the youngest age was obtained for the uppermost flow of the sequence of five. Ages were calculated from isochrons because plateaus were not well defined. A lack of interbedded sediments indicates that the lava field was produced over a short period of time. We use the weighted-mean age of the three ages, $3.70 \pm 0.03 \mathrm{Ma}(2 \sigma)$, as the approximate time for eruption of this field. Along the south side of Water Valley we mapped sequences of several basalt flows. Similar basalt was encountered in drill holes in Water Valley; basalt in one well was sampled (sample MW-186-134, tables 2, 3 [https://doi.org/10.3133/sim3458]; Groover and Izbicki, 2018).

\section{Quaternary Deposits}

Mojave River deposits are recognized by their arkosic composition (Cox and others, 2003) and distinctive rounded quartzite pebbles (Cyr and others, 2015; Miller and others, 2018b). Admixtures of locally derived materials eroded from canyon walls or introduced by tributary streams are present in places. The deposits are recognized in three main locations, each with distinct characteristics (fig. 1). In the Hinkley Valley map area, two deposits occur: west of Iron Mountain in Hawes valley and east of and crossing the southern part of Iron Mountain.

West of Iron Mountain in Hawes valley, a wide sheet of Mojave River fluvial deposits (unit Qomr) extends along Hawes valley north to Harper Basin (Cox and others, 2003). It transitions from an undulating plain in the south to ridge-and-valley terrain nearer Harper Basin. This set of Mojave River fluvial deposits is not directly dated, but the presence of strongly developed stages IV and III calcic soils mantling eroded ridges suggests that the deposits are older than $\sim 500 \mathrm{ka}$ (Miller and others, 2009). One branch of these deposits passes north and northeast of Iron Mountain, entering Hinkley Valley west of the town of Hinkley.

East of and crossing the southern part of Iron Mountain, Mojave River fluvial deposits (unit Qimr) fan out to the north and east. Near Iron Mountain, the deposit lies unconformably on bedrock (Cox and others, 2003). It extends northeast as a thick $(>30 \mathrm{~m})$ clastic wedge. As explored in shallow holes and road cuts, soils developed in these deposits include Bt, Btk, and stage III calcic horizons. These soils are consistent with unit Qia3 ( 300 to $160 \mathrm{ka})$ alluvial-fan deposits (Miller and others, 2009). Less-well-developed soils, in Hinkley Valley as compared to west of Iron Mountain, indicate that deposition in Hinkley Valley outlasted that to the west. Borehole studies west of the town of Hinkley demonstrate two separate pulses of Mojave River sand (Miller and others, 2018a). Age control for unit Qimr is provided by an ash bed cored in several boreholes. The ash is correlated by tephrochronology with the Lava Creek B ash (Miller and others, 2018a) that erupted from the Yellowstone eruptive center in Wyoming about $631 \mathrm{ka}$ (Matthews and others, 2015). The ash lies in the lower part of Mojave River deposits unit Qimr, which locally is greater than $74 \mathrm{~m}$ in thickness. In addition, a chronologic constraint is provided by alluvial-fan deposits with soils characteristic of unit Qia3 that lie on Qimr deposits along the east side of Iron Mountain.

Alluvial-fan deposits are widespread in the map area, where they can be assigned relative ages using surface characteristics and soil development. Eolian sand in the form of sheets, dunes, and coppice dunes is also common, and the blending of eolian and alluvial-fan deposits complicates strict map unit criteria, because the addition of eolian materials modifies both surface characteristics and soils of alluvial fans (Miller and others, 2009). We designate fans with significant eolian additions as units Qyae and Qiae and their subdivisions. These eolianrich fans mainly lie east of Harper Lake and along the Mojave River. Minor eolian additions are more widespread.

Mojave River fluvial deposits associated with the modern river and its terraces extend from south of Iron Mountain toward Barstow. Some of these deposits fan northeastward toward a playa adjacent to Mount General. Northwest of this playa, broad plains are underlain by Mojave River sand and fine gravel that appear to represent fluvial deposits on the basis of gentle ridges associated with pebbly sand, similar to more pronounced inverted stream channels of the older Mojave River deposits farther south. Strata east of Red Hill (fig. 1) are exposed in stream cuts, where lacustrine sediment intervals are sandwiched by Mojave River stream deposits. Weak Bt horizons and stage II calcic soils are associated with the stream deposits and apparently represent late Pleistocene to earliest Holocene soils (Miller and others, 2009).

The modern Mojave River course leads east to Barstow and beyond, but its floodplain, as indicated by deposits of units Qymr2 and Qymr3, also leads northeast to the playa adjacent to Mount General. Multiple recorded periods of high-discharge floods at Barstow (Stamos and others, 2001; Cyr and others, 2015 ) provide a plausibility argument for river flow leading to the playa, from which flow northward down the length of Hinkley Valley is possible. Anecdotal accounts of river flow the length of the valley exist. Enhanced stream flow and wetland development in northern Hinkley Valley and beyond, as described below, supports the view that river flow northward through Hinkley Valley was commonplace before modern levee construction.

Lacustrine sand deposits (unit Qils) east of Red Hill were considered to be 45-40 ka on the basis of luminescence dates, which were older than radiocarbon dates on Anodonta (Garcia and others, 2014). Radiocarbon dates did not young upward in a consistent pattern. We dated a shell above the section to see if any younger shells exist as reported by Meek (1999). The 
result (table 4) was an age similar to those obtained by Garcia and others (2014). We mapped similar lacustrine sediment southward in Hinkley Valley and discovered several sites with highstand-shoreline sediments at Lynx Cat Mountain, Red Hill, and eastern Water Valley (fig. 1). The shoreline sediments lie at elevations of 2,165 to 2,170 ft (660-661 m), which is slightly lower than the playa that lies between the Mojave River channel sediment and the stream traversing northward in Hinkley Valley. The lacustrine deposits dated at 45-40 ka are overlain by Mojave River stream sediment as noted previously. These sediments, in turn, are cut by a subtle notch northwest of Red Hill, below which is a series of nearly horizontal platforms underlain by well-sorted coarse sand derived from the Mojave River that we interpret as lacustrine beach deposits (unit Qyls). This relation indicates that a post-40 ka, lower-level lake that probably did not rise above $2,120 \mathrm{ft}$ (648 m) elevation was sustained in Harper Basin during the latest Pleistocene to early Holocene. Reynolds and Reynolds (1994) suggested that faulting and folding associated with faults in the Eastern California Shear Zone influenced the course of the Mojave River, deflecting it after surface ruptures to cause the Harper Basin to fill. We could find no support for this fault-deflection interpretation because the river switched to both north and east exits from Hinkley Valley during the late Holocene.

Water Valley, the eastern end of Harper Basin (fig. 1), consists of gently west sloping, fine-grained deposits that grade to somewhat steeper slopes farther east in alluvial-fan deposits. The western, nearly flat lying, fine-grained deposits include playa muds (unit Qap) and discharging playa muds (unit Qapw). East of the playa lies a complex region of pale-colored sand and mud (units Qygs, Qygss) that is crossed in much of the area by stream channels that range from conspicuous to very subtle. Overall, as seen on aerial photographs, the area is pale tan to white and displays a pattern of west-flowing channels. On its south, the channels are less evident but can be identified in the field. On the north, large sand dunes cross the deposits; adjacent patches of the fine-grained deposits are not channeled. On the east, the deposits are overlain by young alluvial-fan deposits and by eolian-dune deposits. All deposits lie below the elevation of shoreline deposits (unit Qilg) of Lake Harper. In aggregate, the area of sand and mud from groundwater discharge is greater than $19 \mathrm{~km}^{2}$ and represents significant past groundwater discharge.

Deposits of units Qygs and Qygss in Water Valley consist of brown calcareous sands and muds that are vaguely layered to well layered and contain beds of white calcite nodules and rhizoliths that generally constitute the most resistant beds. In the areas where modern channels are visible, the sediment generally contains beds and lenses of moderately sorted to wellsorted sand similar to the sand in the modern channels. All beds are calcareous. The mud beds are poorly sorted, and floating sand grains are a common occurrence. No identifiable fossils were found, although a few beds contain bone fragments. The deposits bear a strong resemblance to groundwater-discharge deposits throughout the Mojave Desert (for example, Pigati and others, 2011) although they form a broader, more topographically subdued complex than many groundwater-discharge deposits. Thompson (1929) observed that the area hosted rabbit brush and salt grass and exhibited very shallow water in wells.
He suggested that it was a discharging area from Mojave River groundwater exiting Hinkley Valley. Mesquite trees are common today in part of this area, and salt grass is present in a zone of "puffy," very low density, muds adjacent to Harper Lake playa, indicating that discharge still occurs.

The groundwater-discharge deposits are overlain by thin sheets and dunes of eolian sand throughout the map area. Multiple lines of evidence suggest that the sand is historical, whereas the groundwater-discharge deposits predate historical occupation of Water Valley. The top of the groundwater-discharge deposits in many places is a slightly crusted surface, nearly planar and undissected except near channels. This surface appears to have neither degraded nor aggraded where foundations and water troughs were built for early 20th century ranches, although these constructions have eolian sand banked against them. Likewise, fence posts constructed by the ranchers are not eroded or buried, although the wood is moderately split by salt in a zone about $8 \mathrm{~cm}$ above the surface of groundwater-discharge deposits. These observations indicate that the modern surface was the surface utilized on historical ranches, and it has remained stable. The crusted surface consists of a weak calcite crust in otherwise uncemented sediment. No biological crusts were observed. In several places we observed dead stubs, still erect, of shrubs that were once 50-90 cm tall. We suspect that these stubs represent the rabbit brush reported by Thompson (1929).

Stream channels that transect the groundwater-discharge deposits cross much of Water Valley (fig. 3). At their heads, they are fed by streams from alluvial fans of eastern Water Valley and by streams draining Hinkley Valley; at their toes, they drain onto Harper Lake playa. Evidence for modern flow, even near the playa, indicates that many channels are active. Near Blacks Ranch, several stream channels have been modified with culverts, which suggests that flow was common. However, no historical impoundments suitable for watering domestic animals were observed, which implies that stream flow was seasonal or less frequent or that other water sources were abundant. No evidence for springs or gaining-stream activity was observed. However, the channels do not decrease in number toward the playa, suggesting that little transmission loss to underlying sediment occurred. This probably relates to the mud composition of the groundwater-discharge deposits but may also be caused by shallow groundwater.

We found one charcoal-bearing bed in wetland deposits east of Blacks Ranch (sample M16VI-3142, table 4). The bed lies in a distinctly bedded sequence typical of the deposit, at a depth of $45 \mathrm{~cm}$. The radiocarbon age of 1,625 to 1,610 cal yr B.P. indicates that wetland aggradation ceased at or somewhat later than that time.

The channel along much of northeastern Hinkley Valley is straight to slightly meandering, 1 to $4 \mathrm{~m}$ deep, and 50 to $130 \mathrm{~m}$ wide. In the south it is floored by sand and fine gravel, along with young sand dunes, where it exits a playa that is about $661 \mathrm{~m}(2,170 \mathrm{ft})$ elevation. In the north, wide eroded banks in fine to very fine sand are common. In one location (M18IV-386, table 4), streaks of charcoal and cracked rock may represent ancient human occupation. Charcoal fragments, as large as $2 \mathrm{~cm}$ in diameter, show side wood grain consistent with mesquite wood (D. Rhode, Desert Research Institute, written commun., 
2018). A radiocarbon age of 1,610 to $1,525 \mathrm{cal}$ yr B.P. (table 4) indicates that local trees existed at that time, which may have coincided with or shortly postdated perennial flow of the Mojave River down the channel.

The nearly coincident ages for charcoal along the channel leading from the Mojave River (derived from mesquite trees) and charcoal in the wetland indicates that a former river maintained shallow water levels in northern Hinkley Valley for several decades, followed by continuing shallow groundwater discharge in Water Valley.

\section{Quaternary Faults}

Hewett $(1954)$ and Dibblee $(1961,1967)$ recognized from early geologic mapping that numerous youthful faults traverse the Mojave Desert. In the vicinity of Hinkley Valley, we mapped four northwest-striking, right-lateral (dextral) faults (Miller, 2017; Haddon and others, 2018; Miller and others, 2018a) that form the central Mojave Desert part of the Eastern California Shear Zone. From northeast to southwest, they are the Blackwater Fault (exposed for $\sim 2 \mathrm{~km}$ length in the northeast corner of the map) and the Harper Lake, Mount General, and Lockhart Faults (fig. 1 and map, sheet 1).

Two strands of the Blackwater Fault in the Mud Hills form rounded scarps in unit Qia (Amoroso and Miller, 2012). We did not investigate these scarps during this study.

The Harper Lake Fault transitions from two primary strands in the southeast to three in the northwest. The fault zone is $\sim 2.5 \mathrm{~km}$ wide. Hills underlain by Miocene and Pliocene deposits that lie amongst the fault strands indicate uplift and transpressive fault behavior. Uplift is further underscored by observed boulders of Pliocene basalt on hills composed of granite. Scarps in unit Qiae and folding of unit Qya4 indicate youthful tectonism. Adjacent to the northeast strand, excellent exposures of unit QToa demonstrate that several orientations of faults, many with northeast strike, and northwest-trending folds exist. Here, unit QToa contains two ash beds as well as sparse boulders of Pliocene basalt (unit Tbb) that demonstrate the unit is late Pliocene to early Quaternary.

Surface traces of both the Mount General and Lockhart Faults cross Hinkley Valley and may affect the lateral transmission of groundwater. Fault zones are geometrically complex, consisting of several strands that form zones $0.6 \mathrm{~km}$ wide (Mount General) and $1.2 \mathrm{~km}$ wide (Lockhart).

Active traces of the Mount General Fault (also known as the Waterman Fault) define the contemporary east margin of southern Hinkley Valley and cut across late Pleistocene and Holocene surficial deposits and bedrock. Three distinct traces of the Mount General Fault deform the fan piedmont along the linear southwest flank of Mount General, offsetting alluvial-fan channels, levees, and bedrock ridges in a predominantly right-lateral sense. Scarps on Holocene alluvial fans preserve a subsidiary vertical component and consistently face southwest with height as much as $\sim 1.5 \mathrm{~m}$. Quaternary alluvial fans are asymmetric across Mount General, with steep fans on the southwest and gently sloping fans on the northeast. Farther northwest the faults are expressed as linear depressions and faint scarps, as well as co-linear vegetation lineaments. East of Red Hill, however, a vegetation lineament in the modern stream channel does not mark a young fault, because late Pleistocene deposits exposed in the stream banks are not cut by faults. A nearly superimposed feature at this location is a gentle anticline expressed in both unit Qils and unit Qymr4. The inclined base of the latter unit rises nearly to the surface of the Hinkley Valley plain at the crest of the anticline. The folding occurred during deposition of the unit because, as it thins toward the fold crest, soil profiles are not disrupted by erosion. Northwest of Red Hill, the southern strand of the Mount General Fault is a well-defined trace, which we extrapolate farther west as a buried trace. Farther north in Water Valley, linear north-northwest-trending fissures, troughs, and linear dune margins may indicate an active fault strand east of Harper Lake playa. Also to the northwest farther along this trend and beyond the map area, terminations in thick groundwater-discharge deposits and moderately to steeply west dipping mineralized faults are co-linear with the probable fault shown on the map. In Water Valley, several north-northeast-trending fissures cut the unit Qygss groundwater-discharge deposits; most fissures terminate at or near the inferred fault strand. Similar fissures occur in the playa north of the Mojave River and adjacent to the Mount General Fault Zone. Knott (1992) described a single fissure where it cut old Route 58. Based on repeat imagery, that fissure has lengthened and two others have now formed. Although Dibblee (1960a) showed the Mount General Fault cutting deposits farther southeast and through central Barstow, we found no definitive evidence for the fault in those locations. Patterns of bedrock at depth in Hinkley Valley (fig. 3) can be interpreted to indicate unfaulted bedrock between the Lockhart and Mount General Faults. If so, dextral offset on the Mount General Fault is about $2 \mathrm{~km}$ and dextral offset on the Lockhart Fault is $2.5 \mathrm{~km}$ or more.

Anastomosing strands of the Lockhart Fault Zone in southern Hinkley Valley merge from the Lenwood Fault farther south (figs. 1, 3). East of the town of Lenwood, the north end of the Lenwood Fault Zone cuts units QToa and QTgw deposits and displays scarps in late Pleistocene unit Qia deposits. The eastern strand displaces the top of a unit QTgw deposit in a right lateral sense about $113 \mathrm{~m}$. The beds here dip $22-24^{\circ}$ to the southwest, so any component of vertical offset will influence the actual slip considerably. We identified an additional western strand characterized by shear zones in unit Qia deposits that pass northward into Lenwood. Together these main strands arc to a more westerly strike near the Mojave River and transition to the Lockhart Fault Zone. The Lockhart Fault Zone crosses Pleistocene Mojave River deposits (unit Qimr) northwest of the Mojave River, where it is expressed as a series of linear depressions and rounded scarps with a sense of down to the north. One recently active strand cuts a Holocene river terrace deposit. Relatively old apparent dextral offsets of ridge-and-swale topography formed on middle Pleistocene unit Qimr show distributed shear on individual fault traces within the zone. The northernmost strand of the Lockhart Fault near the Mojave River coincides with a steep gravity gradient and an apparent $\sim 3 \mathrm{~km}$ offset of a buried low-density deposit indicating that, at this latitude, the north strand of the Lenwood Fault is most active over the long term. The long-term pattern of deformation, based on core studies of key stratigraphic units at depth (Miller and others, 2018a), includes folding and overall down-tothe-north offset within the Lockhart Fault Zone. 


\section{Borehole Stratigraphy}

To build a depositional architecture for sediments in Hinkley Valley and adjacent parts of Water Valley, we evaluated selected core material by studying sediment attributes that can elucidate three properties: provenance, depositional setting, and age. These properties are evaluated by standard sedimentologic methods, study of fossils, and chronologic methods including tephrochronology (table 6).

We examined all sediment core, representing several hundred wells, in reconnaissance and selected core from 137 wells that provided the most information on (1) spatial distribution of sediment, (2) sediment cored from the surface to great depth, (3) details in and near the Lockhart Fault Zone, and (4) specific depositional features and hydrologic questions. The studied core totaled 3,616 $\mathrm{m}(11,865 \mathrm{ft})$ in length. Many wells were cored only below the modern water table, commonly $18 \mathrm{~m}(60 \mathrm{ft})$ or more below the surface. Borehole logs made available to us aided with interpreting the unsaturated zone but we were unable to assign provenance to intervals that were not cored. As a result, sections of wells that were not cored were not interpreted. Well locations are shown in figure 3 and listed in table 7 (https://doi.org/10.3133/sim3458), which provides summary properties. Core logs are shown on sheet 2. A synthesis of core logs along the length of Hinkley Valley was presented by Miller and others (2018a).

\section{Descriptions of Depositional Environment}

Reconnaissance of sediment cores from Hinkley Valley revealed a wide range of coarse to fine sand, muds, a locally thick ash bed, calcium-carbonate-charged sand and silt, and gravelly materials overlying bedrock. Using metrics of size

Table 6. Criteria for interpretations of provenance, depositional environment, and age of core sediment, Hinkley Valley and vicinity, San Bernardino County, California.

\begin{tabular}{|c|c|c|}
\hline Property & Classification & Criteria \\
\hline \multirow[t]{3}{*}{ Provenance } & Mojave River stream & $\begin{array}{l}\text { Source in Transverse Ranges indicated by arkose with quartzite lithic grains; rounded to well-round- } \\
\text { ed coarse and very coarse grains }\end{array}$ \\
\hline & Local alluvial fan & $\begin{array}{l}\text { Source in local hills indicated by lithics similar to local bedrock, including volcanic rock, siliceous } \\
\text { materials, and metamorphic rock; angular to subangular grains dominate }\end{array}$ \\
\hline & Uncertain & Grain size is medium sand and finer; lithics and rounding not distinctive \\
\hline \multirow[t]{6}{*}{$\begin{array}{l}\text { Depositional } \\
\text { environment }\end{array}$} & $\begin{array}{l}\text { Mojave River stream } \\
\text { system }\end{array}$ & $\begin{array}{l}\text { Coarse stream-channel deposits are poorly sorted, crudely bedded; crevasse splay deposits are poorly } \\
\text { sorted sandy to gravelly muds; low-energy depositional sites similar to lake and delta environments } \\
\text { exist but only in thin sequences within channel deposit sequence; lacks fossils. Color is orangish tan } \\
\text { to brown or gray. Soils common in upper } 2-6 \mathrm{~m} \text { of section, less common } 6-12 \mathrm{~m} \text { depth }\end{array}$ \\
\hline & Local alluvial fan & $\begin{array}{l}\text { Poorly sorted, vaguely bedded gravel and sand of local provenance; commonly several soils within } \\
\text { sequence; lacks fossils. Color yellow brown to red brown. Includes thick intervals of fine-grained } \\
\text { to very fine grained sand in Water Valley that is medium bedded but poorly sorted, characteristic } \\
\text { of distal piedmont setting. Sequences overlying bedrock in several wells characterized by weath- } \\
\text { ered bedrock materials interspersed with thin beds of sand; may indicate pediment deposits }\end{array}$ \\
\hline & $\begin{array}{l}\text { Lake margin (near- } \\
\text { shore lake, delta, } \\
\text { beach) }\end{array}$ & $\begin{array}{l}\text { Moderately sorted to well-sorted sand and silt with sparse gravelly sand interbeds at most; thin bedded } \\
\text { to laminated (but varies in a few cases to thick beds); commonly mica-rich; highly variable overall; } \\
\text { sparse fossils indicate shallow lake environment. May represent fluvial delta, beach, and nearshore } \\
\text { lake deposits or playa-margin deposits. Color white to gray, tan to pale tan, and rich brown. Com- } \\
\text { monly calcareous and (or) micaceous. Includes single thick beds of poorly sorted Mojave River } \\
\text { sediment that may represent tongues of stream incursion into a delta, shallow lake, or playa setting }\end{array}$ \\
\hline & Lake & $\begin{array}{l}\text { Clay and silt to very fine sand, thinly bedded to laminated; commonly rippled; generally not calcare- } \\
\text { ous; fossils indicate shallow lake environment. Color is gray, green, olive, tan, white, and gley; } \\
\text { ranges to brown near base and top. Commonly diatomaceous. No evidence of dropstones }\end{array}$ \\
\hline & Mudflat or playa & $\begin{array}{l}\text { Fine sand to silt and clay; mostly poorly sorted with admixture of coarse and very coarse sand grains; } \\
\text { sand grains floating in mud very common. Rare mud cracks and thin stream sheetflow beds taken to } \\
\text { indicate playa environment. Calcareous nodules and zones of } \mathrm{MnO}_{2} \text { stain are common; sparse fossils } \\
\text { indicate shallow lake environment. Color is brown and orangish brown, ranging to tan }\end{array}$ \\
\hline & Groundwater discharge & $\begin{array}{l}\text { Calcium-carbonate-rich sediment, typically with alluvial-fan lithics and sand grains floating in a fine } \\
\text { sand to silt composed of detrital grains and carbonate material. Very poorly sorted overall. Sand and } \\
\text { pebble grains uniformly coated by } \mathrm{CaCO}_{3} \text {. Carbonate found in underlying deposits, including rock, } \\
\text { along cracks. Color is pale gray or pale tan to white; rarely rich brown with } 50 \text { percent calcite muds }\end{array}$ \\
\hline \multirow[t]{3}{*}{ Age } & $\begin{array}{l}\text { Late Pleistocene to } \\
\text { early Holocene }\end{array}$ & $\begin{array}{l}\text { Surface morphology of well site, shallow soils consistent with young age; only one or two soils in } \\
\text { sequence in core }\end{array}$ \\
\hline & Middle Pleistocene & Surface morphology of well site, multiple soils in sequence in core; geochronologic control \\
\hline & Early Pleistocene & Surface morphology of well site, geochronologic control \\
\hline
\end{tabular}


sorting, rounding of grains, bedding characteristics, small-scalesedimentary structures, soil horizons, and oxidation state, three depositional environments can be confidently identified: alluvial fan, groundwater-discharge, and lacustrine deposits (table 7).

Three more depositional environments are clearly indicated for some sediment but ambiguous for others: Mojave River stream system, playa or mudflat, and an aggregate of lake-margin environments (nearshore lake, delta, and beach).

Unlike core study, outcrop investigations provide better assessment of several properties that could reduce the provenance uncertainty for the three ambiguous deposits. Outcrop studies demonstrate that stream deposits of the Mojave River are conspicuously bedded, moderately sorted, lack in soils and other evidence of infrequent deposition, and include sediments that can be readily assigned to crevasse splay deposits, as well as quiet-water deposits along the margins of streams in floodplains and oxbow lakes (Cox and others, 2003). In sediment cores, coarse-grained stream deposits are clearly identifiable, but finer-grained deposits that are moderately well sorted and thinly bedded may represent either low-energy stream environments such as floodplain deposits or delta and lake-margin environments; these deposits are assigned by the context of enclosing deposits because the specific environments rarely are distinctive in core samples.

Oxidized, poorly sorted mud, muddy sand, and fine sand may represent playa deposits. However, these deposits rarely exhibit mud cracks and, in some cases, are clay rich. The deposits are calcareous and commonly have $\mathrm{CaCO}_{3}$ and $\mathrm{MnO}_{2}$ blebs. The deposits may, in part, represent wet and dry mudflat environments of broad, shallow ponds and nearby associated sediment, similar to discharging playas.

Nearshore lake, delta, and beach deposits have several characteristics in common, such as thin bedding, moderately sorted to well-sorted materials, and primarily fine to medium sand. They typically are tan and olive in color but, in some cases, are pale gray. Context of the deposit commonly provides the most appropriate depositional environment, but many deposits cannot be readily divided and, as a result, we use a single term, "lake margin," for these deposits. Coarse-grained sand assigned to the lake-margin environment is composed of rounded quartz and feldspar grains characteristic of the Mojave River deposits but is better sorted and thick bedded. It is considered to represent beach environments.

\section{Provenance}

Provenance can be unambiguously assigned to local stream sources as opposed to Mojave River sources by evaluation of lithic grains and degree of rounding of coarse and very coarse sand grains. Mojave River sediments are sourced in the Transverse Ranges and composed of quartz-rich arkose with distinctive reddish, well-rounded, quartzite pebbles in coarser beds (Miller and others, 2018b). Coarse sand grains typically are moderately to well rounded. In contrast, local sources are typified by lithic sands that include volcanic rocks, metamorphic rocks, and mafic granitoids. Sand grains and pebbles are angular to subangular. Local alluvial-fan deposits also can be distinguished by the presence of multiple soil horizons along with the poor sorting and irregular bedding characteristics of alluvial-fan environments.

Ambiguities in assigning provenance occur with arkosic sands that are medium grained and finer. Locally sand from grus-generating granite sources in Lynx Cat Mountain and the eastern Water Valley area (fig. 1) are similar to Mojave River sediment if lithics are not present, and sand in this size range also may be transported by eolian processes. For these sands, a local source was assumed if the core site was near an appropriate alluvial fan and other sediment in the core was demonstrably local.

\section{Depositional Patterns}

Sediment core from boreholes in Hinkley Valley demonstrates that ancestral Mojave River deposits underlie the entire valley, in some places from the surface to depths greater than $60 \mathrm{~m}$. Several boreholes penetrated alluvial-fan deposits below the Mojave River deposits, and the depth to the top of the fans, along with depth to crystalline bedrock underlying the Mojave River deposits, permit the shape of Hinkley Valley prior to Mojave River incursion to be outlined (Miller and others, 2018a). The underlying alluvial fans carry local bedrock clasts, unlike the Mojave River deposits, and clast provenance matching rock in mountains adjacent to Hinkley Valley indicates fans and streams draining from the southwest, east, and north into a valley with two low, internally drained centers that likely were playas. One borehole penetrated moderately sorted axial stream sand and gravel (BG-01, sheet 2) that carried clasts from piedmonts both south and west of the site, indicating flow to the northeast.

Overlying the local alluvial fans and bedrock, a suite of Mojave River deposits constitutes most of the fill of Hinkley Valley. In general, thin groundwater-discharge deposits (for example, Pigati and others, 2011) and Mojave River stream deposits of the south-central Hinkley Valley are overlain by an extensive lake deposit associated with the Mojave River. The groundwater-discharge deposits are carbonate-rich sand and silt deposits bearing rounded grains and quartzite pebbles indicative of Mojave River derivation. Two groundwater-discharge deposits are present in some boreholes south of the community of Hinkley, and in a few boreholes the two are separated by alluvial-fan sediment of local provenance, which indicates that the Mojave River and its sediment load entered Hinkley Valley to form wetlands twice (fig. 1, ancestral Mojave River deposits I and II; sheet 2, wells MW-122, MW-159, MW-167). The extensive lake deposit overlying the groundwater-discharge deposits interfingers with Mojave River stream and delta deposits to the south, and in this same area a thick lens of volcanic ash lies within stream and delta deposits. White to gray, fine ash was collected from 44 cores for analysis and visually identified in another 10 cores on the basis of color, texture, and shard morphology. Electron microprobe analysis of these glass shards indicates that the ash is chemically highly similar to the Lava Creek B ash bed (Miller and others, 2018a) that erupted from the Yellowstone eruptive center about $631 \mathrm{ka}$ (Matthews and 
others, 2015). Thickness of the ash bed exceeds $1 \mathrm{~m}$ in nine wells $3 \mathrm{~km}$ southeast of Hinkley, and maximum thickness is greater than $6 \mathrm{~m}$. We interpret this area of thick ash deposits as the location of local stream input. The ash lies in deposits above both groundwater-discharge deposits, demonstrating that the lake associated with the second incursion of Mojave River sediment received the ash; its location indicates that the first incursion entered from north of Iron Mountain and the second entered from south of Iron Mountain.

The lake deposits occupy the lower fill sequence in the southern and central part of Hinkley Valley. They are gray to gley or white in color and are composed of silt, very fine sand, and clay. White beds and laminae contain abundant diatoms. Deposits commonly are 6 to $10 \mathrm{~m}$ thick but are as thick as $23 \mathrm{~m}$. Although reduced and generally noncalcareous, near the top and bottom of the sequence the sediments are, in places, calcareous with colors ranging to olive, indicating more oxidized conditions. Ripple structure is common, indicating deposition above wave base or in an area with bottom currents. Lake deposits at the time of ash deposition occupied a basin about $8 \mathrm{~km}$ north to south (Miller and others, 2018a) that had more than $20 \mathrm{~m}$ of relief, indicating a deep lake. Lake deposits consistently are gradationally overlain by lake-margin deposits, indicating a gradual lessening of water inflow but persistence of stream-tolake environments through much of the filling of the valley.

A thick sequence of lake-margin deposits (delta, beach, and nearshore lake) that are interlayered with subordinate mudflat and stream deposits overlies the lake deposits and also interfingers with Mojave River stream deposits in the southwest. Upward, the facies repeat several times, although there is one broad mass of mudflat deposits in the northern part of Hinkley Valley (Miller and others, 2018a). Mudflat and playa intervals indicate less inflow, intermittent wetting of the valley, and, perhaps, confinement by a low sill near Red Hill that caused ponding.

The uppermost 15-30 m of sediment is mainly Mojave River stream sediment that thins northward. Soils are rarely observed in much of the stratigraphic sequence but are found in the uppermost $\sim 7 \mathrm{~m}$ (sheet 2). We consider this observation to indicate that sediment rapidly filled most of Hinkley Valley with few, if any, interruptions. In the north end of the valley, soils are developed on the Mojave River stream sediment, above which is a sequence of 45-40 ka lake sediment (Garcia and others, 2014) and a thin (2-3 m thick) sheet of Mojave River stream deposits (sheet 2).

\section{Chronology}

Deposits that underlie the Mojave River sediment in Hinkley Valley are not directly dated. However, unit QToa deposits are exposed south of the valley (sheet 1) where they are early Quaternary (Cox and others, 2003; Miller and others 2018a). Correlative deposits may underlie the southern part of the valley.

The ash bed commonly found in the reduced lake interval is correlated with the Lava Creek B ash (Miller and others, 2018a), which erupted from the Yellowstone eruptive center $\sim 631 \mathrm{ka}$ (Matthews and others, 2015). It was deposited in the upper part of the reduced lake-bed sequence (sheet 2), providing a middle Pleistocene age constraint for that unit.
Depositional rates for the Mojave River system can be determined from parts of the system that have age control from radiocarbon-dated fossils. We use silty lake deposits of Soda Lake (Honke and others, 2019) as an analog for the reduced lake deposits of Hinkley Valley. The Soda Lake deposits accumulated at $1.20 \mathrm{~m} / 1,000 \mathrm{yr}$. This rate yields $20 \mathrm{k} . \mathrm{y}$. for deposition of the thickest $(23 \mathrm{~m}$ ) lake section in Hinkley Valley. Typical lake thicknesses of 6 to $10 \mathrm{~m}$ would have required 5 to $8.3 \mathrm{k}$.y. to accumulate. Although $10 \mathrm{~m}$ of lake sediment lies above the ash in one core, typical thicknesses above the ash are 3 to $4 \mathrm{~m}$. About 2.5-3.5 k.y. would be required to accumulate this lake sediment above the Lava Creek B ash. We therefore place the beginning of lake deposition about 640 to $635 \mathrm{ka}$ and the end at about 628 $\mathrm{ka}$. The lake-margin sediment is best approximated by the fluvial delta of Lake Manix (Reheis and others, 2012), which accumulated at $1.54 \mathrm{~m} / 1,000 \mathrm{yr}$. A typical thickness of $15 \mathrm{~m}$ in Hinkley Valley, therefore, was deposited in about 10 k.y. Mojave River stream deposits near Coyote Lake overlie dated lake sediments and lead to a shoreline of known age (Miller and others, 2018b) providing a depositional rate of $2.69 \mathrm{~m} / 1,000 \mathrm{yr}$. This rate would yield a time of about $10 \mathrm{k} . \mathrm{y}$. for deposition of a typical $26 \mathrm{~m}$ thickness of stream deposits in Hinkley Valley. The maximum thickness, about $55 \mathrm{~m}$, would require about $21 \mathrm{k} . \mathrm{y}$. We estimate that the south-central valley filled between 640 and $605 \mathrm{ka}$, which corresponds to much of Marine Isotope Stage 16 and part of the following Stage 15. Timing for the northern valley with its common mudflat deposits is more difficult to establish.

\section{Deformation of Buried Strata near the Lockhart Fault Zone}

Deformation of several horizons within the depositional sequence can be illustrated in and near the Lockhart Fault Zone. Figure $5 A$ displays elevations tabulated for 50 wells for which core was examined plus 14 wells studied in reconnaissance (fig. 5B). Elevations are presented for ground surface, the top of the reduced-lake interval, the base of the Lava Creek B ash bed, and the water table. The top of the reduced-lake interval may be time-transgressive to an unknown degree, but the base of the ash bed probably represents nearly isochronous deposition. The ash probably was deposited regionally and transported to the lake within one wet season. It may have continued to be deposited episodically for several years, but the initial deposition in the lake was essentially isochronous. The data in figure $5 \mathrm{~A}$ were assembled from a 2-km length of the fault zone (fig. $5 B$ ), along which the strata generally slope gently eastward. As a result, elevations at any given distance from the fault vary by as much as $5 \mathrm{~m}$.

The ash bed slopes gently northeast at a distance from 1,000 to 2,500 m northeast of the north strand of the Lockhart Fault (fig. 5A). Southward and closer to the north strand, it steepens in a fold or rises in a series of faults that we did not map. Within the Lockhart Fault Zone, it continues to steeply rise southward; its highest point is about $25 \mathrm{~m}$ above the projected slope of the bed to the north.

The top of the lake interval is less well constrained than the ash bed, because it is a gradational contact in a few cores and because it is potentially time transgressive. Nonetheless, the top 


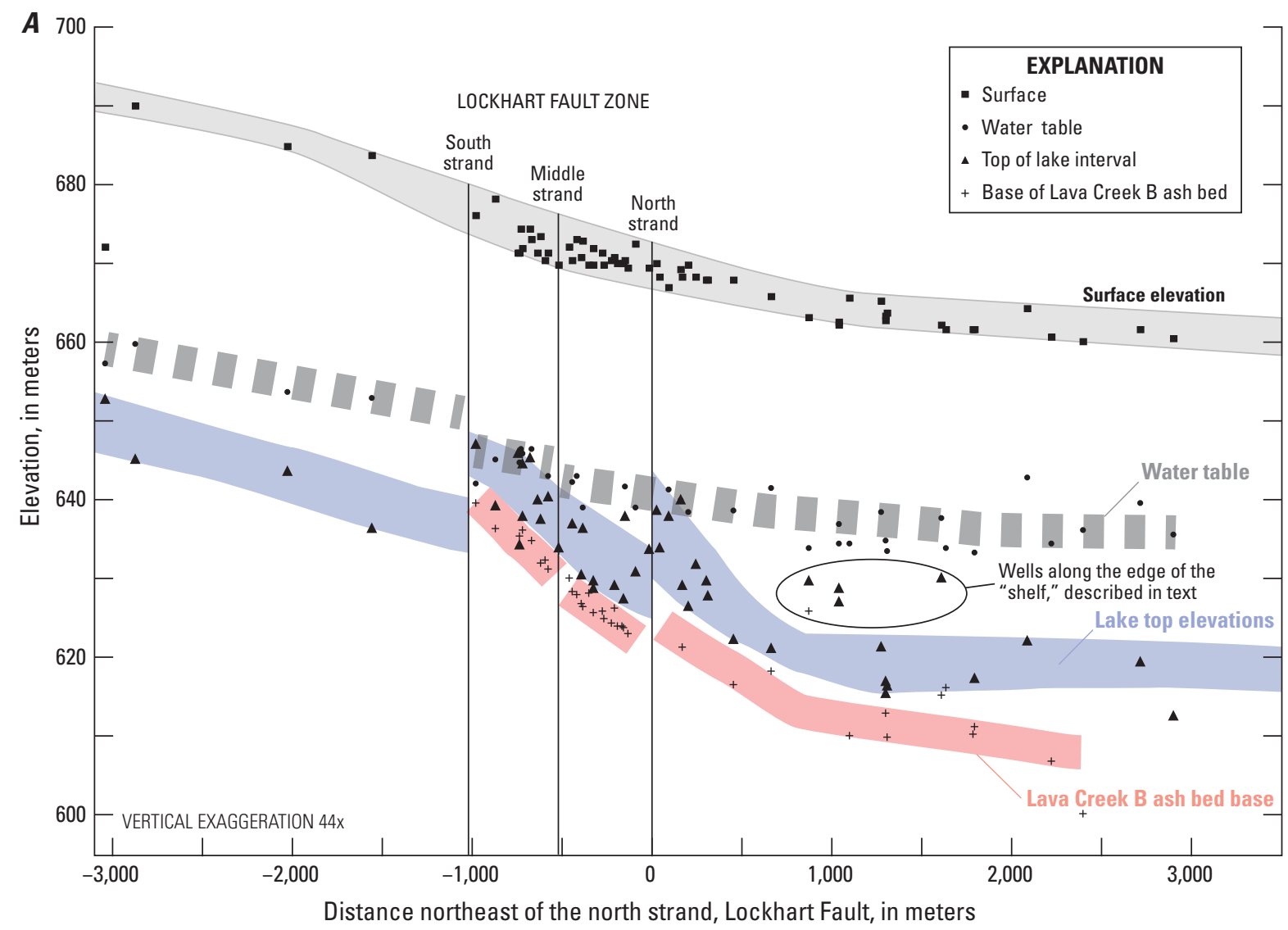

Figure 5. A. Cross section of Lockhart Fault Zone showing disruption of horizons detected in sediment core. Section is perpendicular to the fault zone and aggregates information from all wells in $B$. Water table depths north of the fault zone may vary due to pumping by extraction wells. $B$. Enlargement of geologic map area (location shown on sheet 1) showing locations of wells used in cross section shown in $A$. Borehole core data available in table 7 (https://doi.org/10.3133/sim3458).

of the lake interval displays the same deformation characteristics as the ash bed: it rises in elevation southward within $\sim 400 \mathrm{~m}$ of the north strand of the fault and drops down to the south across the northern and southern fault strands. The top of the lake interval south of the fault zone appears to be about $13 \mathrm{~m}$ higher than a simple projection from the north.

The lake basin in which the ash bed was deposited may have had a steeper bottom slope in the south and a flatter bottom to the north, as indicated by figure $5 \mathrm{~A}$. This conclusion is supported by the thinning of the lake interval southward (sheet 2), as if toward the margin of the lake. If this were the case, the steeper slope accounts for some of the higher elevations of the ash bed and lake interval south of the fault. Steep dips for key sediment horizons within the fault zone and steps in the water table across fault strands indicate that the fault zone had deformed the valley fill, and this deformation, as well as presence of fault-zone gouge, affects lateral flow of groundwater. In addition to southward thinning of the lake sequence, it thins and rises in the west near the bedrock shelf interpreted from gravity data of the western valley. Wells MW-028, EX-29, PZ-07, EX-03, and MW-031C (sheet 2) all exhibit elevations for the top of the lake interval and the ash bed that are 10 to $20 \mathrm{~m}$ higher than those units in wells a short distance to the east. These five wells are not deformed, because water-table and surface elevations match the nearby wells. We interpret this cluster of higher elevations for the tops of the lake interval and the ash bed in the wells as deposition on the margin of a bedrock high.

\section{Deposits of Water Valley}

Deposits studied in core material from Water Valley, mostly from wells along or near Hinkley Road, displayed several differences compared with core material from Hinkley Valley. Throughout the core, lithics are entirely of local origin. Mojave River sand, identified by well-rounded coarse and very coarse grains of quartz and feldspar, is most abundant below 30 to $45 \mathrm{~m}$ depth in the cores. The sand may represent beach sand worked around the Harper Basin by alongshore transport. Above this possible beach sand is a thick section of repeating facies of poorly sorted sand and muddy sand, along with two or three calciumcarbonate-cemented hardgrounds. These repeated sections probably represent lacustrine deposition, with the hardgrounds formed during drying of the lakes. A few of the wells bottomed into basalt that is chemically similar to basalt in outcrop to the east, which has been identified as the Black Mountain basalt (table 2). 


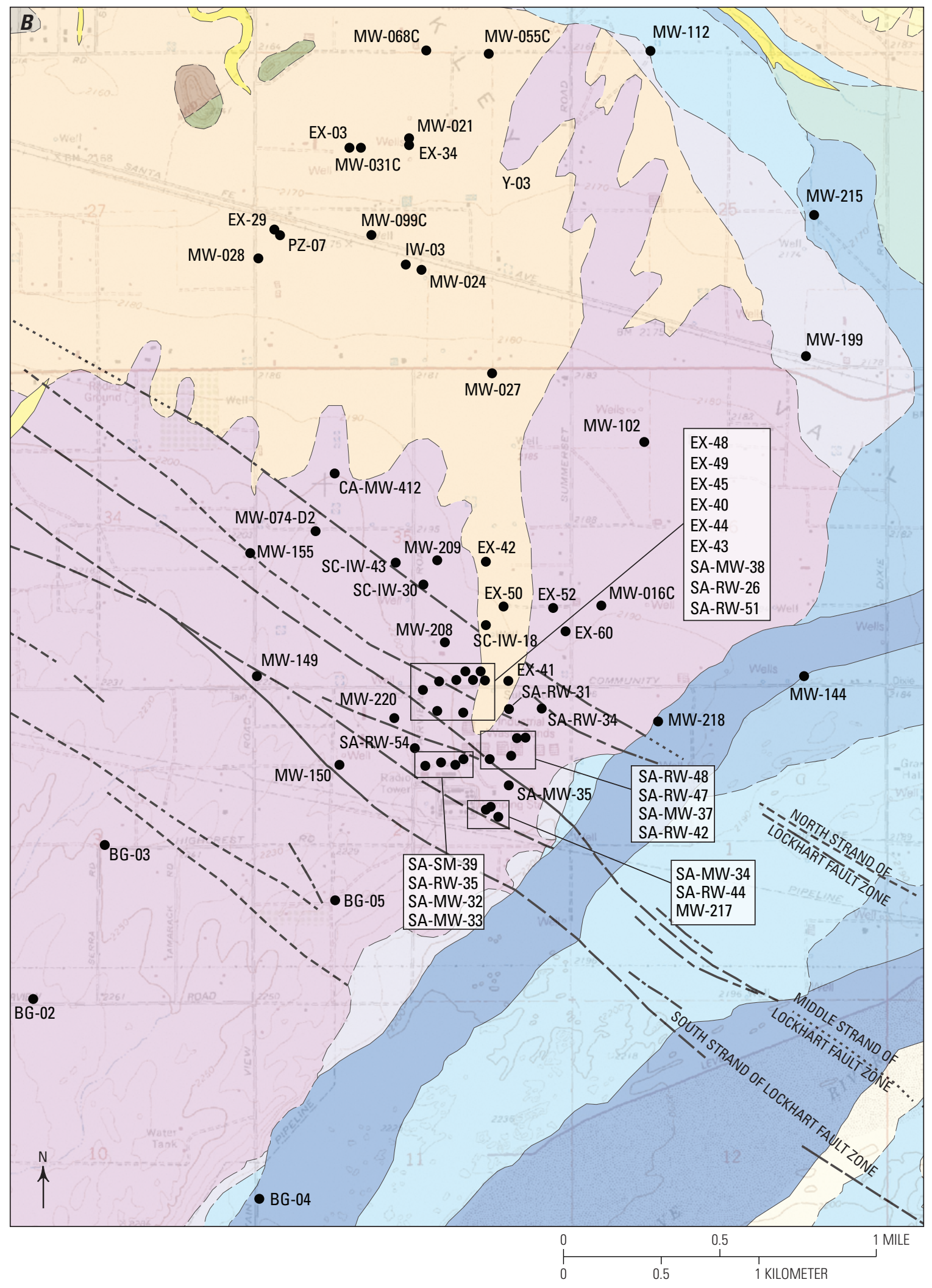

Figure 5. Continued 


\section{Hydrologic Implications}

Floods in the Mojave River channel along the south side of Hinkley Valley raise groundwater levels and recharge groundwater to the rest of the valley as pulses of groundwater that flow laterally northward through the valley (Stamos and others, 2001). Groundwater currently flows north along the length of the valley, exiting at a bedrock narrows near Red Hill. Historically, Water Valley beyond Red Hill had very shallow groundwater with artesian flow in a few places (Thompson, 1929). The lateral conductivity of deposits, depth to bedrock or other low conductivity materials, and faults may influence the paths and rates of groundwater flow.

Previous geologic maps classified deposits of the southern Hinkley Valley as unfaulted recent and older alluvium (Bowen, 1954; Dibblee, 1960a), implying that the deposits are locally derived alluvial-fan deposits. Alluvial fan deposits consist of lenticular beds of poorly sorted materials and typically bear numerous soils. As a result they tend to conduct groundwater poorly. We have shown that many of these previously mapped alluvial-fan deposits are ancestral Mojave River (early? to middle Pleistocene) stream deposits and that they are cut by several strike-slip fault strands. Ancestral Mojave River stream sediment is mapped from the Mojave River northward beyond the Lockhart Fault Zone and is present at depth throughout the valley; it ranges from 18 to $30 \mathrm{~m}$ in thickness (sheet 2; Miller and others, 2018a). These deposits are coarse grained and bear soils only near the modern surface. They have longitudinal connectivity, creating fast flow parallel to the former stream flow, which is down the topographic gradient to the north. Younger (late Pleistocene to Holocene) Mojave River fluvial sediment is known near the surface in the northern part of the valley. The other coarse-grained sediment in the valley, alluvial fans derived from local mountains, bear numerous soil horizons and lack longitudinal connectivity; any existing connectivity is crosswise to the gradient of the valley. As a result, lateral conductivity in the Mojave River deposits is much greater than that expected for deposits previously represented on geologic maps. Thus, the Mojave River deposits now recognized as the dominant sedimentary regime of Hinkley Valley require updated models for groundwater flow.

The thickness of valley fill in Hinkley Valley is variable, from negligible to as much as $120 \mathrm{~m}$ (fig. 4C); it could be even thicker where it overlies the gravity low near the Mojave River. Most of the western valley north of the town of Hinkley has gravity values modeled as depth to bedrock of less than $60 \mathrm{~m}$, the shallowest increment identified in the figure. North of the town, wells reach bedrock at depths as shallow as $25 \mathrm{~m}$. This bedrock shelf as outlined by gravity data and supported by well data may cause a northward constriction of deep flow in basinal sediments. As groundwater levels declined during decades of overdraft, easily pumped groundwater was increasingly limited to the eastern part of the valley. This restriction may be represented by constriction of the mapped plume of hexavalent chromium $(\mathrm{Cr}(\mathrm{VI})$, Izbicki and Groover, 2018, fig. 6).

Two fault zones cross Hinkley Valley between the Mojave River and the low point near Red Hill. Each consists of multiple strands. Steps in groundwater levels near the Lockhart Fault (Stamos and others, 2001; this report, fig. 5A) demonstrate that it is a partial barrier to lateral flow. Retarded flow across the fault, but faster flow around the southeast end of the fault where young deposits of the Mojave River channel probably have only minor development of fault materials such as gouge, probably leads to most recharge to Hinkley Valley taking place in a limited part of southeastern Hinkley Valley. Hydrologic effects of the Mount General Fault Zone are less certain; groundwater steps are not apparent (and fewer data on groundwater levels are available), and the fault is oblique to flow direction of groundwater.

The relatively high lateral conductivity of groundwater in Mojave River stream deposits has a direct bearing on plumes of $\mathrm{Cr}(\mathrm{VI})$, which were described by Izbicki and Groover (2018). Transport of $\mathrm{Cr}(\mathrm{VI})$ from the point of release may be much faster than expected for more typical desert alluvial-fan materials. In addition, ancestral Mojave River deposits have been shown to carry greater concentrations of $\mathrm{Cr}$ than younger Mojave River sediments (Groover and Izbicki, 2019). The widespread older Mojave River deposits of Hinkley Valley must be factored into contaminant models.

$\mathrm{Cr}(\mathrm{VI})$ release was from a location within the Lockhart Fault Zone. We map several fault strands south of the release point and several to the north. The hydrologic character of individual fault strands is not known, and it is possible that more fault strands exist. Uncertainties associated with the Lockhart Fault Zone result in difficulty predicting the effects of the fault strands on groundwater movement. Future work needed includes (1) better definition of the locations of fault strands by trenching and geophysical studies, (2) detailed study of water flow across and parallel to the fault strands, and (3) better characterization of faults and sediments in the modern Mojave River channel.

\section{Geologic Map}

\section{Geologic Mapping Conventions}

This geologic map emphasizes description and interpretation of late Cenozoic deposits because, in general, older rocks are crystalline and dense and have much less abundant and recoverable groundwater in comparison to younger more porous deposits. The older rocks vary considerably in age and composition, and their material properties play large roles in determining the properties of sediment eroded from them, and they therefore are classified by general groupings of age and composition.

\section{Composite Symbols}

Surficial geologic deposits in places form thin $(<2-3 \mathrm{~m})$ veneers over older units. Where this relation is common, the unit designators are shown separated by a slash (/). Indicated first is the younger or overlying deposit. Unit label Qya/Qia, for example, indicates an area where a veneer of young alluvial-fan deposits overlies intermediate alluvial-fan deposits and Qia/mp indicates an area where a veneer of intermediate alluvial-fan deposits overlies mafic plutonic rocks.

The lateral extent of individual deposits is commonly so small that each deposit cannot be shown individually at the map scale. Such areas are indicated by two unit labels separated by a plus sign $(+)$, with the most common deposit listed first. Thus, Qya+Qia 
indicates an area with both Qya and Qia deposits and that Qya is more common than Qia. Deposits composing less than 20 percent of the area in a polygon are not included in the unit label.

\section{Acknowledgments}

Geologic mapping and borehole core logs are products of a cooperative study for the Lahontan Regional Water Quality Control Board that added to prior mapping conducted for the National Cooperative Geologic Mapping Program of the U.S. Geological Survey. We thank cooperators in PG\&E and its contractors, who

\section{References Cited}

Amoroso, L., and Miller, D.M., 2012, Surficial geologic map of the Cuddeback Lake 30' x 60' quadrangle, San Bernardino and Kern Counties, California: U.S. Geological Survey Scientific Investigations Map 3107, scale 1:100,000, 31 p.

Anderson, R.E., 2017, Major revision of the timing, style, magnitude, and cause of early Miocene extension in the central Mojave metamorphic core complex and subsequent role of the eastern California shear zone, in Reynolds, R.E., ed., ECSZ does it, revisiting the eastern California shear zone: Desert Symposium, California State University, Fullerton, p. 60-70.

Andrew, J.E., and Walker, J.D., 2017, Path and amount of dextral fault slip in the eastern California shear zone across the central Mojave Desert: Geological Society of America Bulletin, v. 129, no. 7-8, p. 855-868.

Blakely, R.J., and Simpson, R.W., 1986, Approximating the edges of source bodies from magnetic or gravity anomalies: Geophysics, v. 51, p. 1494-1498.

Boettcher, S.S., 1990, Geologic map of Iron Mountain: Geological Society of America Digital Map and Chart Series 19, scale 1:12,000, https://doi.org/10.1130/1990-boettcherironmountain.

Bowen, O.E., Jr., 1954, Geology and mineral deposits of the Barstow quadrangle, San Bernardino County, California: California Division of Mines Bulletin 165, p. 1-185.

Briggs, I.C., 1974, Machine contouring using minimum curvature: Geophysics, v. 39, p. 39-48.

California Department of Water Resources, 2003, California's Groundwater: California Department of Water Resources Bulletin $118,246 \mathrm{p}$.

Cordell, L., and Grauch, V.J.S., 1985, Mapping basement magnetization zones from aeromagnetic data in the San Juan Basin, New Mexico, in Hinze, W.J., ed., The utility of regional gravity and magnetic anomaly maps: Society of Exploration Geophysicists, p. 181-192.

Cox, B.F., Hillhouse, J.W., and Owen, L.A., 2003, Pliocene and Pleistocene evolution of the Mojave River, and associated tectonic development of the Transverse Ranges and Mojave Desert, based on borehole stratigraphy studies and mapping of landforms and sediments near Victorville, California, in Enzel, Y., Wells, S.G., and Lancaster, N., eds., Paleoenvironments made sediment cores and borehole data available to us and took an active interest in our work. Discussions with John Izbicki, Krishangi Groover, Chris Maxwell, Ernie Anderson, and Nate Onderdonk helped us to interpret the deposits of Hinkley Valley and surrounding ranges. Elmira Wan and Laura Walkup analyzed several samples of ash from core and outcrop, providing correlations with known ash beds that clarified the ages of depositional units. Scott Starratt and Jordon Bright identified diatom and ostracode fossils. Andy Cyr helped with core logging and interpreting the geomorphology of the area. Dave Rhode kindly evaluated charcoal to identify its probable species. Jack McGeehin contributed radiocarbon expertise. We thank Andy Morita for collecting gravity data. Reviews by Krishangi Groover and Paul Stone are appreciated.

and paleohydrology of the Mojave and southern Great Basin Deserts: Boulder, Colorado, Geological Society of America Special Paper 368, p. 1-42.

Cyr, A.J., Miller, D.M., and Mahan, S.A., 2015, Paleodischarge of the Mojave River, southwestern United States, investigated with single-pebble measurements of ${ }^{10} \mathrm{Be}$ : Geosphere, v. 11, no. 4, p. 1158-1171.

Dibblee, T.W., Jr., 1960a, Geologic map of the Barstow quadrangle, San Bernardino County, California: U.S. Geological Survey Mineral Investigations Field Studies Map MF-233, scale 1:62,500.

Dibblee, T.W., Jr., 1960b, Geologic map of the Hawes quadrangle, San Bernardino County, California: U.S. Geological Survey Mineral Investigations Field Studies Map MF-226, scale 1:62,500.

Dibblee, T.W., Jr., 1961, Evidence of strike-slip movement on northwest-trending faults in the western Mojave Desert, California: U.S. Geological Survey Professional Paper 424-B, p. B197-199.

Dibblee, T.W., Jr., 1967, Areal geology of the western Mojave Desert, California: U.S. Geological Survey Professional Paper 522, p. 1-153.

Dibblee, T.W., Jr., 1968, Geology of the Fremont Peak and Opal Mountain quadrangles, California; California Division of Mines and Geology Bulletin 188, scale 1:62,500.

Dokka, R.K., 1986, Patterns and modes of early Miocene crustal extension, central Mojave Desert, California, in Extensional tectonics of the southwestern United States - A perspective on processes and kinematics: Geological Society of America Special Paper 208, p. 75-95.

Dokka, R.K., 1989, The Mojave extensional belt of southern California: Tectonics, v. 8, p. 363-390.

Dokka, R.K., and Travis, C.J., 1990, Late Cenozoic strike-slip faulting in the Mojave Desert, California: Tectonics, v. 9, no. 2, p. 311-340.

Dudash, S.L., 2006, Preliminary surficial geologic map of a Calico Mountains piedmont and part of Coyote Lake, Mojave Desert, San Bernardino County, California: U.S. Geological Survey Open-File Report 2006-1090, 44 p., scale 1:24,000.

Fillmore, R.P., and Walker, J.D., 1996, Evolution of a supradetachment extensional basin-The lower Miocene Pickhandle basin, central Mojave Desert, California, in Beratan, K.K., 
ed., Reconstructing the history of Basin and Range extension using sedimentology and stratigraphy: Geological Society of America Special Paper 303, p. 107-126.

Fletcher, J.M., Bartley, J.M., Martin, M.W., Glazner, A.F., and Walker, J.D., 1995, Large-magnitude continental extensionAn example from the central Mojave metamorphic core complex: Geological Society of America Bulletin, v. 107, p. $1468-1483$.

Fletcher, J.M., and Martin, M.W., 1998, Geologic map of the Hinkley Hills: Geological Society of America Digital Map and Chart Series, scale 1:12,000, last accessed March 2017 at http://www.geosociety.org/maps/1998-fletcher-hinkleyhills/.

Fletcher, J.M., Miller, J.S., Martin, M.W., Boettcher, S.S., Glazner, A.F., and Bartley, J.M., 2002, Cretaceous arc in the Mojave block-Profound crustal modification that controlled subsequent tectonic regimes, in Glazner, A.F., Walker, J.D., and Bartley, J.M., eds., Geologic evolution of the Mojave Desert and southwestern Basin and Range: Geological Society of America Memoir 195, p. 19-41.

Garcia, A.L., Knott, J.R., Bright, J. , and Mahan, S.A., 2014, Geochronology and paleoenvironment of pluvial Harper Lake, Mojave Desert, California: Quaternary Research, v. 81, p. 305-317.

Glazner, A.F., and Bartley, J.M., 1994, Eruption of alkali basalts during crustal shortening in southern California: Tectonics, v. 13 , p. 493-498.

Glazner, A.F., Walker, J.D., Bartley, J.M., and Fletcher, J.M., 2002, Cenozoic evolution of the Mojave block of southern California, in Glazner, A.F., Walker, J.D., and Bartley, J.M., eds., Geologic evolution of the Mojave Desert and southwestern Basin and Range: Geological Society of America Memoir 195, p. 19-41.

Groover, K.D., and Izbicki, J.A., 2018, Field portable X-ray fluorescence and associated quality control data for the western Mojave Desert, San Bernardino County, California: U.S. Geological Survey data release, https://doi.org/10.5066/ P9CU0EH3.

Groover, K.D., and Izbicki, J.A., 2019, Selected trace-elements in alluvium and rocks, western Mojave Desert, southern California: Journal of Geochemical Exploration, v. 200, p. 234-248.

Haddon, E.K., Miller, D.M., Langenheim, V.E., Liu, Tanzhuo, Walkup, L.C., and Wan, Elmira, 2018, Initiation and rate of slip on the Lockhart and Mount General faults in southern Hinkley Valley, California, in Miller, D.M., ed., Against the currentThe Mojave River from sink to source: Desert Symposium, Inc., p. 56-57, http://desertsymposium.org/About.html.

Hewett, D.F., 1954, General geology of the Mojave Desert region, California, in Jahns, R.H., ed., Geology of southern California: Californian Division of Mines and Geology, Bulletin 170, v. II, p. 5-20.

Honke, J.S., Piagati, J.S., Wilson, J., Bright, J., Goldstein, H.L., Skipp, G.L., Rehheis, M.C., and Havens, J.C., 2019, Late Quaternary paleohydrology of desert wetlands and pluvial lakes in the Soda Lake basin, central Mojave Desert, California (USA): Quaternary Science Reviews, v. 216, p. 89-106.
Ingram, W.M., 1948, The larger freshwater clams of California, Oregon, and Washington: Journal of Entomology and Zoology, v. 40, p. 72-92.

Izbicki, J.A., and Groover, K.D., 2018, Natural and man-made hexavalent chromium, $\mathrm{Cr}(\mathrm{VI})$, in groundwater near a mapped plume, Hinkley California-Study progress as of May 2017, and a summative-scale approach to estimate background $\mathrm{Cr}(\mathrm{VI})$ concentrations: U.S. Geological Survey Open-File Report 2018-1045, 28 p.

Jachens, R.C., and Langenheim, V.E., 2014, Gravity survey and interpretation of Fort Irwin and vicinity, Mojave Desert, California, in Buesch, D.C., ed., Geology and geophysics applied to groundwater hydrology at Fort Irwin, California: U.S. Geological Survey Open-File Report 2013-1024H, 15 p.

Jachens, R.C., Langenheim, V.E., and Matti, J.C., 2002, Relationship of the 1999 Hector Mine and 1992 Landers fault ruptures to offsets on Neogene faults and distribution of late Cenozoic basins in the eastern California shear zone: Bulletin of Seismological Society of America, v. 92, p. 1592-1605.

Jachens, R.C., and Moring, B.C., 1990, Maps of the thickness of Cenozoic deposits and the isostatic gravity over basement for Nevada: U.S. Geological Survey Open-File Report 90-404, 15 p.

Knott, J.R., 1992, Effects and mitigation of ground fissuring along state highway 58, Hinkley Valley, San Bernardino County, California: Proceedings of the 35th annual meeting of the Association of Engineering Geologists, October 2-9, 1992, Long Beach, CA, v. 35, p. 134-142.

Knott, J.R., Sarna-Wojcicki, A.M., Machette, M.N., and Klinger, R.E., 2005 Upper Neogene stratigraphy and tectonics of Death Valley-A review: Earth-Science Reviews, v. 73, p. 245-270.

Langenheim, V.E., and Jachens, R.C., 2014, Aeromagnetic data, processing, and maps of Fort Irwin and vicinity, California, chap. I of Buesch, D.C., ed., Geology and geophysics applied to groundwater hydrology at Fort Irwin, California: U.S. Geological Survey Open-File Report 2013-1024, 18 p., http:// dx.doi.org/10.3133/ofr20131024I.

Langenheim, V.E., Morita, A.Y., Martin, A.J., Jordan, J., and Haddon, E.K., 2019, Gravity data of the Hinkley area, southern California: U.S. Geological Survey data release, https://doi. org/10.5066/P9FV5LG5.

Mabey, D.R., 1960, Gravity survey of the west Mojave Desert, California: U.S. Geological Survey Professional Paper 316-D, 73 p., 3 plates.

MacFadden, B.J., Swisher, C.C., Opdyke, N.D., and Woodburne, M.O., 1990, Paleomagnetism, geochronology, and possible tectonic rotation of the middle Miocene Barstow Formation, Mojave Desert, southern California: Geological Society of America Bulletin, v. 102, p. 478-493.

Maizels, J., 1990, Raised channel systems as indicators of palaeohydrologic change - a case study from Oman: Palaeogeography, Palaeoclimatology, Palaeoecology, v. 76, p. 241-277.

Martin, M.W., and Walker, J.D., 1991, Upper Precambrian to Paleozoic paleogeographic reconstruction of the Mojave Desert, California, in Cooper, J.D., and Stevens, C.H., eds., 
Paleozoic Paleogeography of the Western United States-II: Pacific Section, SEPM, v. 67, p. 167-192.

Matthews, N.E., Vazquez, J.A., and Calvert A.T., 2015, Age of the Lava Creek supereruption and magma chamber assembly at Yellowstone based on ${ }^{40} \mathrm{Ar} /{ }^{39} \mathrm{Ar}$ and $\mathrm{U}-\mathrm{Pb}$ dating of sanidine and zircon crystals: Geochemistry, Geophysics, Geosystems, v. 16, p. 2508-2528, https://doi.org/10.1002/2015GC005881.

Meek, N., 1999, New discoveries about the late Wisconsin history of the Mojave River system, in Reynolds, R.E., and Reynolds, J., eds., Tracks along the Mojave - A field guide from Cajon Pass to the Calico Mountains and Coyote Lake: Redlands, California, San Bernardino County Museum Association Quarterly, v. 46, no. 3, p. 113-117.

Miller, D.M., 2017, The late Cenozoic Eastern California Shear Zone after 25 years of study, in Reynolds, R.E., ed., Revisiting the Eastern California Shear Zone: California State University, Fullerton, Desert Studies Consortium, p. 45-54, http://www. desertsymposium.org/DS_2017_ECSZ_does_it.pdf.

Miller, D.M., Bedford, D.R, Hughson, D.L., McDonald, E.V., Robinson, S.E., and Schmidt, K.M., 2009, Mapping Mojave Desert ecosystem properties with surficial geology, in Webb, R.H., Fenstermakes, L.F., Heaton, J.S., Highson, D.L., McDonald, E.V., and Miller, D.M., eds., The Mojave Desert—Ecosystem processes and sustainability: University of Nevada Press, p. 225-251.

Miller, D.M., Dudash, S.L, Green, H.L., Lidke, D.J., Amoroso, L., Phelps, G.A., and Schmidt, K.M., 2007, A new Quaternary view of northern Mojave Desert tectonics suggests changing fault patterns during the late Pleistocene, in Miller, D.M., and Valin, Z.C., eds., Geomorphology and tectonics at the intersection of Silurian and Death Valleys, southern California: U.S. Geological Survey Open-File Report 2007-1424, p. 157-171, http://pubs.usgs.gov/of/2007/1424/of2007-1424.pdf.

Miller, D.M., Dudash, S.L., and McGeehin, J.P., 2018b, Paleoclimate record for Lake Coyote, California, and the LGM deglacial paleohydrology (25-14 cal ka) of the Mojave River, in Starratt, S.W., and Rosen, M.R., eds., From saline to freshwater-The diversity of western lakes in space and time: Geological Society of America Special Paper 536, https://doi. org/10.1130/2018.2536(12).

Miller, D.M., Haddon, E.K., Langenheim, V.E., Cyr, A.J., Wan, E., Walkup L.C., and Starratt, S.W., 2018a, Middle Pleistocene infill of Hinkley Valley by Mojave River sediment and associated lake sediment-Depositional architecture and deformation by strike-slip faults, in Miller, D.M., ed., Against the currentThe Mojave River from sink to source: Desert Symposium, Inc., p. 58-65, http://www.desertsymposium.org/2018 DS Against the Current.pdf.

Miller, J.S., Glazner, A.F., Walker, J.D., and Martin, M.W., 1995, Geochronologic and isotopic evidence for Triassic-Jurassic emplacement of the eugeoclinal allochthon in the Mojave Desert region, California: Geological Society of America Bulletin, v. 107, p. 1441-1457.

Morin, R.L., 1995, Isostatic gravity map of the Victorville 1:100,000-scale quadrangle, California: U.S. Geological Survey Open-File Report 95-16, https://doi.org/10.3133/ofr9516.
Oskin, M., and Iriondo, A., 2004, Large-magnitude transient strain accumulation on the Blackwater fault, eastern California shear zone: Geology, v. 32, p. 313-316, https://doi. org/10.1130/G20223.1.

Pigati, J.S., Miller, D.M., Bright, J.E., Mahan, S.A., Nekola, J.C., and Paces, J.B., 2011, Chronology, sedimentology, and microfauna of groundwater discharge deposits in the central Mojave Desert, Valley Wells, California: Geological Society of America Bulletin, v. 123, p. 2224-2239.

Reheis, M.C., Bright, J., Lund, S.P., Miller, D.M., Skipp, G., and Fleck, R.J., 2012, A half-million-year record of paleoclimate from the Lake Manix core, Mojave Desert, California: Palaeogeography, Palaeoclimatology, Palaeoecology, v. 365-366, p. 11-37.

Reimer, P.J., Bard, E., Bayliss, A., Beck, J.W., Blackwell, P.G., Ramsey, C.B., Buck, C.E., Cheng, H., Edwards, R.L., Friedrich, M., Grootes, P.M., Guilderson, T.P., Haflidason, H., Hajdas, I., Hatter, C., Heaton, T.J., Hoffmann, D.L., Hogg, A.G., Hughen, K.A., Kaiser, K.F., Kromer, B., Manning, S.W., Niu, M., Reimer, R.W., Richards, D.A., Scott, E.M., Southon, J.R., Staff, R.A., Turney, C.S.M., and van der Plicht, J., 2013, INTCAL13 and MARINE13 radiocarbon age calibration curves, 0-50,000 years cal BP: Radiocarbon, v. 55, p. 1869-1887.

Reynolds, R.E., and Reynolds, R.L., 1994, The isolation of Harper Lake basin, in Reynolds, R.E., ed., Off limits in the Mojave Desert: Redlands, California, San Bernardino County Museum Association Special Publication 94-1, p. 34-37.

Saltus, R.W., and Jachens, R.C., 1995, Gravity and basin-depth maps of the Basin and Range Province, western United States: Geophysical Investigation Map 1012, scale 1:250,000.

Stamos, C.L., Martin, P., Nishikawa, T., and Cox, B.F., 2001, Simulation of ground-water flow in the Mojave River basin, California: U.S. Geological Survey Water-Resources Investigations Report 01-4002, 129 p.

Subsurface Surveys, 1990, Inventory of groundwater stored in the Mojave River basins: Unpublished report prepared by Subsurface Surveys, Inc. (215 South Highway 101, Suite 203, Solana Beach, CA 92075 USA) for the Mojave Water Agency, Apple Valley, California, 47 p.

Tang, R.W., and Ponce, D.A., 1982, Principal facts, accuracies, sources, and base station descriptions for 4,915 gravity stations on the San Bernardino $1^{\circ} \times 2^{\circ}$ quadrangle, California: U.S. Geological Survey NTIS PB-82-200312 (available from U.S. Department of Commerce, National Technical Information Service, Springfield, VA 22161), 99 p.

Telford, W.M., Geldart, L.O., Sheriff, R.E., and Keyes, D.A., 1976, Applied geophysics: New York, Cambridge University Press, 960 p.

Thompson, D.G., 1929, The Mojave Desert region, CaliforniaA geographic, geologic, and hydrologic reconnaissance: U.S. Geological Survey Water-Supply Paper 578, 759 p.

Walker, J.D., Fletcher, J.M., Fillmore, R.P., Martin, M.W., Taylor, W.J., Glazner, A.F., and Bartley, J.M., 1995, Connection between igneous activity and extension in the central Mojave metamorphic core complex: Journal of Geophysical Research, v. 100, p. $10,474-10,494$. 